PNL-3261

TTC-0073

UC-71

\title{
Application of ALARA Principles to Shipment of Spent Nuclear Fuel
}

\author{
J. Greenborg \\ L. W. Brackenbush \\ D. W. Murphy \\ R. A. Burnett \\ J. R. Lewis
}

May 1980

Prepared for Sandia National Laboratories'

Transportation Technology Center for the United States Department of Energy under Contract DE-AC06-76RLO 1830

Pacific Northwest Laboratory Operated for the U.S. Department of Energy by Battelle Memorial Institute 


\title{
NOTICE
}

This report was prepared as an account of work sponsored by the United States Government. Neither the United States nor the Department of Energy, nor any of their employees, nor any of their contractors, subcontractors, or their employees, makes any warranty, express or implied, or assumes any legal liability or responsibility for the accuracy. completeness or usefulness of any information, apparatus, product or process disclosed, or represents that its use would not infringe privately owned rights.

The views, opinions and conclusions contained in this report are those of the contractor and do not necessarily represent those of the United States Government or the United States Department of Energy.

\author{
PACIFIC NORTHWEST LABORATORY \\ operated by \\ BATTELLE \\ for the \\ UNITED STATES DEPARTMENT OF ENERGY \\ Under Contract DE-AC06-76RLO 1830
}

\author{
Printed in the United States of America \\ Available from \\ National Technical Information Service \\ United States Department of Commerce \\ 5285 Port Royal Road \\ Springfield, Virginia 22151
}

Price: Printed Copy 5

$\because$ Microfiche $\$ 3.00$

- Pages Selling Price

\begin{tabular}{ll}
\hline $001-025$ & $\$ 4.00$ \\
$026-050$ & $\$ 4.50$ \\
$051-075$ & $\$ 5.25$ \\
$076-100$ & $\$ 6.00$ \\
$101-125$ & $\$ 6.50$ \\
$126-150$ & $\$ 7.25$ \\
$151-175$ & $\$ 8.00$ \\
$176-200$ & $\$ 9.00$ \\
$201-225$ & $\$ 9.25$ \\
$226-250$ & $\$ 9.50$ \\
$251-275$ & $\$ 10.75$ \\
$276-300$ & $\$ 11.00$
\end{tabular}


APPLICATION OF ALARA PRINCIPLES TO SHIPMENT

OF SPENT NUCLEAR FUEL
J. Greenborg
L. W. Brackenbush
D. W. Murphy
R. A. Burnett
J. R. Lewis

May 1980

Prepared for Sandia National Laboratories' Transportation Technology Center for the United States Department of Energy under Contract DE-AC06-76RLO 1830

Pacific Northwest Laboratory

Richland, Washington 99352 
.

6

. 


\section{CONTENTS}

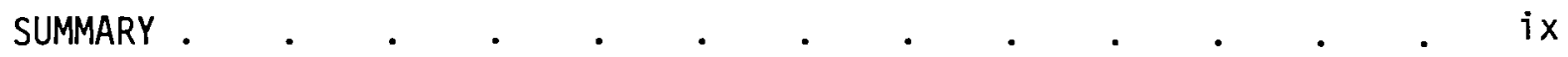

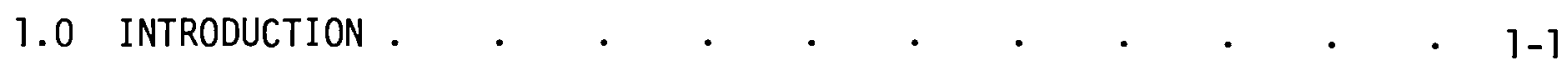

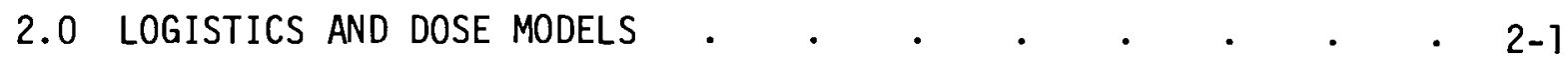

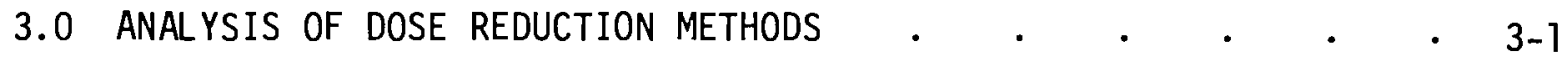

3. 1 SPENT FUEL STORAGE OPTIONS • .

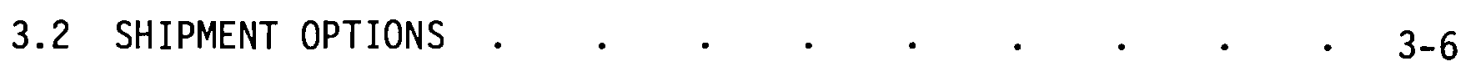

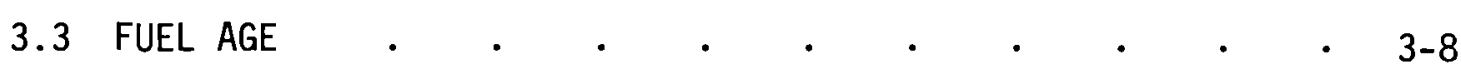

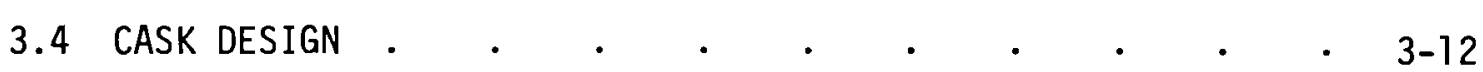

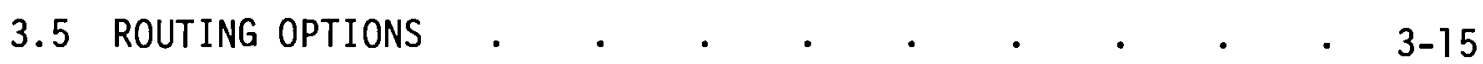

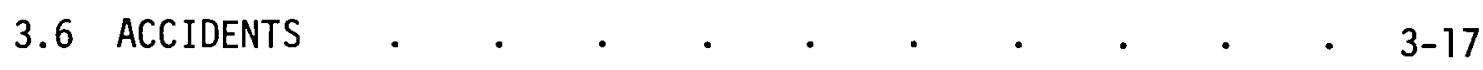

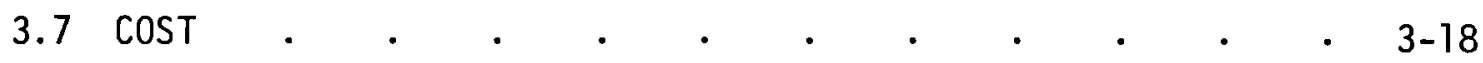

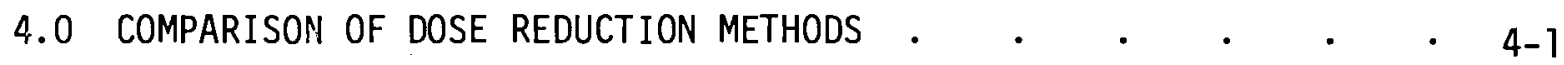

REFERENCES $\quad$ •

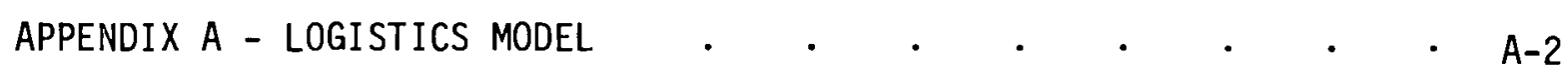

APPENDIX B - SHIPPING CASK SHIELDING ANALYSIS . • • • • • • B-2

APPENDIX C - POPULATION EXPOSURE MODEL . . . . . . . . . C C-2

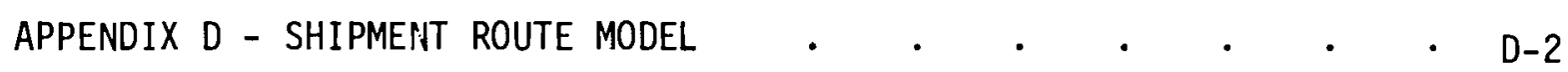

APPENDIX E - DOSE INTEGRATION MODEL • • • • • • • • • • E-2

APPENDIX $F$ - CASK CAPACITY VS FUEL AGE AND DOSE RATE SPECIFICATION - F-2

APPENDIX G - TRANSPORT ACCIDENT DATA (NUCLEAR AND NON-NUCLEAR) • • G-2 


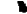

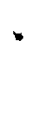




\section{FIGURES}

3.1 NFS-4 and NLI 10/24 Dose Rates $10 \mathrm{ft}$ From Cask Centerline.

3.2 Public and Occupational Dose Rate for Spent Fuel Shipment vs Average Fuel Age.

\section{TABLES}

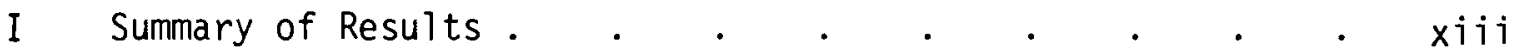

2.1 Installed Nuclear Electric Generation Capacity Used in 2-1 the Study

2.2 Spent Fuel Logistics Conditions . . . . . . . . 2-3

2.3 Reference Shipping Cask Specifications . . . . . 2-4

3.1 Summary of the Spent Fuel Logistic Cases . . . . 3-2

3.2 Cumulative Radiation Dose for Subsequent Shipment of All Spent Fuel Discharged From Reactors Through 1990; Three Storage/ Logistics Scenarios . . . . . . . . . 3-4

3.3 Public and Occupational Radiation Dose - From Shipment of Spent Fuel in the 11-year period 1980-1990; Three Storage/Logistics Scenarios

3.4 Average Dose to a Person Exposed to a Spent Fuel Shipment - 3-7

3.5 Radiation Dose for Truck and Rail Shipment . . . . 3-9

3.6 Effect of Cask Design on Population Dose (Case 3, FCR, Rerack to $31 / 3$ Core) 3-13

3.7 Cask Capacity and Weight vs. Dose and Fuel Age . . . 3-14

3.8 Spent Fuel Shipment Dose: Effect of Rerouting Around Metropolitan Areas (Case 1; FCR, No Rerack, Truck Shipment . 3-16

3.9 Potential Fatalities Attributable to Spent Nuclear Fuel Transport . . . . . . . . . . . . $3-17$ 
3.10 Conversion Factors for Population Dose: Maximum Number of 3-18 Health Effects

3.11 Projected Nuclear Industry Spent Fuel Shipping Costs (1976) 3-19

3.12 Shipping Tariffs (1) (1976) . . . . . . . . 3-20

4.1 Logistics Policy Comparison: Spent Fuel Shipping Dose,

4.2 Technology Options (Compared to Logistics Case 1, 1980-1990) . $.0 . \quad . \quad . \quad . \quad . \quad 4-3$

A.1 Spent Fuel Shipments - Case 1, FCR, No Rerack . . . A-3

A.2 Spent Fuel Shipments - Case 2, No FCR, No Rerack . . A-4

A.3 Spent Fuel Shipments - Case 3, FCR, Rerack to 10/3 Cores . A-5

A.4 Fuel Age Distribution in Transport, \% by age . . . . A-6

B. 1 Truck Cab Dose Rate, PWR . . . . . . . . B-3

B.2 Truck Cask K Factors, PWR $\left(m r e m-m^{2} / h r\right)$. . . . . B-4

B.3 Train Cask K Factors, PWR (mrem-m $\left.\mathrm{m}^{2} / \mathrm{hr}\right)$. . . . B-4

B.4 Spent PWR Fuel Element Description . . . . . . . B-5

B.5 NFS-4 Cask Description (in.) . . . . . . . . . B-5

B. 6 NLI 10/24 Cask Description (in.) . . . . . . . . . . B-6

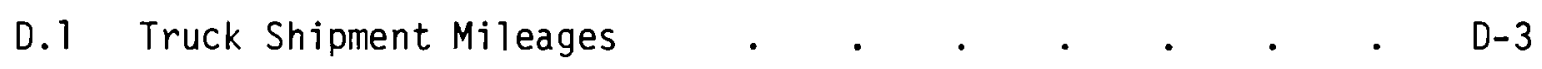

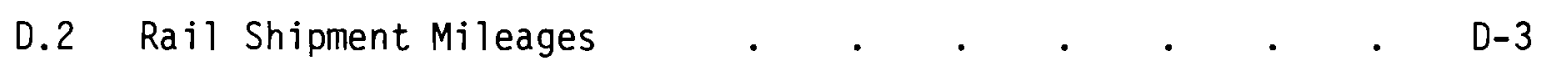

D. 3 Comparison of Rail/Truck Mileages _ . . . . . . . . . . D-3

F.1 Truck Cask Capacity and Weight Vs. Age, $10 \mathrm{mrem} / \mathrm{hr}--$
$6 \mathrm{ft}$ From Vehicle Surface . . . . . . . . F-3

F.2 Rail Casks Capacity and Weight Vs. Age, $10 \mathrm{mrem} / \mathrm{hr}--$
$6 \mathrm{ft}$ From Personnel Barrier . . . . . . . . . . F-4

F.3 Truck Cask Capacity and Weight Vs. Age, $1 \mathrm{mrem} / \mathrm{hr}--$
$6 \mathrm{ft}$ From Vehicle Surface . . F-5 


\section{$\underline{\text { TABLES }}$}

F.4 Rail Cask Capacity and Weight Vs. Age, $1 \mathrm{mrem} / \mathrm{hr}$ a $6 \mathrm{ft}$

From Vehicle Surface . . . . . . . . . F-6

G.1 Population Doses for Postulated Spent Fuel Shipping

Accidents

G-3 
. 


\section{$\underline{\text { SUMMARY }}$}

The frequency of spent fuel shipments will increase in the coming years as additional reactor plants fill their spent fuel storage facilities and as additional away-from-reactor (AFR) storage facilities are completed. This will result in a corresponding increase in the exposure of transportation workers and the general public to the low levels of radiation emitted from spent fuel shipping casks during transport. The maximum external radiation dose rate for spent fuel shipping casks is regulated by the Department of Transportation and the Nuclear Regulatory Commission. Recently, the possibility of reducing these maximum dose rates has been discussed, as has the possibility of requiring that these shipments maintain dose as low as reasonably achievable (ALARA). This report presents the results of a study performed by Pacific Northwest Laboratory (PNL) for the Transportation Technology Center, operated for DOE by Sandia Laboratories. The objectives of this study were to examine the implications of adopting various dose reduction alternatives for spent fuel shipments, and to identify and evaluate the parameters that most affect the radiation dose.

Radiation exposure from shipments of spent fuel will comprise only a small amount of the total exposure experienced in the U.S. If current shipping practices are followed, spent fuel shipments will result in about $100 \mathrm{man}-\mathrm{rem} /$ year of radiation exposure during the period 1980 to 1990 . This exposure can be compared to the 40 million man-rem of radiation exposure received annually by the U.S. population from natural sources, medical examination, television and air travel. Of the 100 additional man-rem generated by spent fuel shipments, less than 10 man-rem will be received by the general population. The balance will be received by workers in the nuclear and transportation industries. Although the spent fuel shipment dose is small, there is incentive to reduce this exposure, particularly the occupational dose. With this goal in mind, the alternatives for dose reduction examined in this study include: shipping schedule changes (a function of reactor plant spent fuel storage capacity), shipment modes (rail and truck), fuel age, cask design and alternate routings. 
Spent fuel is produced as a by-product of the operation of nuclear power plants. After discharge from the reactor, the fuel is stored in onsite water basins and subsequently shipped offsite for storage and eventual disposal. The quantities in shipment reflect the actual onsite reactor plant storage capacities, the spent fuel discharge rates, and the facilities, policies and regulations which apply to spent fuel disposal. In order to provide accurate radiation exposure analysis, it was necessary to accurately model the current state of the nuclear industry, the shipping technology, and the routings of the spent fuel shipments. Most operating plants were designed and built to promptly ship spent fuel for reprocessing; i.e., with a spent fuel storage pool sized to accommodate 1-1/3 cores (one year's discharge plus additional reserved space for discharge of the full core $^{(a)}$ to accommodate reactor repairs). The indefinite deferral of reprocessing has resulted in most new plants seeking licenses for added storage capacity by use of high density reracking and/or construction of larger pools. This has resulted in considerable uncertainty about the logistics of future shipments of spent fuel. Increasing the spent fuel storage capacity at the reactor plants reduces spent fuel shipment dose because the fuel will have undergone a longer period of radioactive decay before it is shipped and because extended storage at the reactor may enable the fuel to be shipped directly to a repository. This would eliminate the need for secondary shipments from an AFR to the disposal site. For these reasons, three spent fuel storage/shipping logistics cases were examined in the study. These cases represent the range of possible scenarios that could be expected. The cases examined include:

1. no reracking of storage pools allowed, FCR $^{(a)}$ maintained (base case),

2. no reracking, FCR not maintained, and

3. existing, and new, reactor plants reracked to maximum capacity (typically 10/3 core or greater) but FCR maintained.

These cases result in fuel shipments with average fuel ages of 2.4, 5.7 and 6.9 years respectively.

(a) Full core reserve (FCR). 
Table I summarizes the key findings of this study. If currently available spent fuel shipping casks are used, the case 1 logistics option results in a cumulative radiation dose of 11,600 man-rem for shipment of all fuel discharged by the U.S. reactor plants through 1990. By comparison, logistics case 3 results in a cumulative dose of 3,400 man-rem. These calculations assume the existence of a repository that accepts spent fuel by 1985 . That is, with a repository available in 1985 , case 1 would result in about $95 \%$ of the spent fuel being shipped to an AFR and the other 5\% directly to the repository. Case 3 results in $5 \%$ of the fuel being shipped to the AFR and 95\% directly to the repository. If a repository is not available until 1995, all fuel would be shipped directly to an AFR in both cases 1 and 3 and eventually shipped from the AFR to a repository. This results in shipment doses of about 11,800 and 6,400 man-rem respectively for these two cases. Results for case 2 are intermediate to the results of cases 1 and 3.

Current generation spent fuel casks were designed to accommodate spent fuel that had been discharged from a reactor as little as 120 days prior to shipment. All spent fuel storage/shipment options currently considered possible result in average fuel ages considerably greater than the 120-day design basis for current casks. These casks, therefore, have more radiation shielding and greater heat removal capabilities than are needed for fuel anticipated to be shipped in the 1980s. It is possible that a new generation of casks will be developed that are designed specifically for longer-cooled fuel. The effects of using these casks for logisitics case 3 is shown in Table I. Use of these casks designed to current regulations for external dose rates would result in substantially increased radiation exposures, primarily because existing casks are over-designed for this fuel. These casks would also result in a substantial reduction in shipping costs. The possibility of changing the regulations for allowable external dose rates from shipping casks has also been evaluated. The results for a cask external dose rate of $1 \mathrm{mR} / \mathrm{hr}$ at $2 \mathrm{~m}$ from the cask surface is shown in Table $\mathrm{I}$. This would reduce radiation exposure by a factor of four compared to a new cask fleet designed for $10 \mathrm{mR} / \mathrm{hr}$ at $2 \mathrm{~m}$ from the cask surface. Shipping costs would be increased by about $10 \%$. 
Alternate routing schemes to bypass high population regions for the purpose of dose reduction were found to be ineffective. Alternative routing will reduce exposure to residents and travelers enroute by about $1 / 3$, but the increased dose to the truck drivers and bystanders at truck stops (resulting from the longer shipping distances) will more than offset the reductions.

In conclusion, the public exposure from spent fuel shipment is very low. In view of this low exposure and the perfect safety record for spent fuel shipment, existing systems can be considered satisfactory. On the other hand, occupational exposure reduction merits consideration and technology improvement to decrease dose should concentrate on this exposure. Practices that affect the age of spent fuel in shipment and the number of times the fuel must be shipped prior to disposal have the largest impact. A policy to encourage a 5-year spent fuel cooling period prior to shipment coupled with appropriate cask redesign to accommodate larger loads would be consistent with ALARA and economic principles. And finally, bypassing high population density areas will not in general reduce shipment dose. 


\section{TABLE I. Summary of Results}

Cases $\quad \begin{aligned} & \text { Cumulative } \\ & \text { Shipment Dose } \\ & \text { man-rem }\end{aligned}$

Logistics Case $3^{(c)}$ (ship aged fuel)

$\begin{array}{ll}\times & \text { Redesign Casks for aged } \\ \exists & \text { fuel (Logistics Case } 3 \text { ) }\end{array}$

Current regulations

Reduced Dose Rate Requirements

Reroute to avoid high population density
11,600

3,400

13,500

3,300

No Change
Cost

(1976 \$M)

1,070

580

430

460

Sma 11

Increase

(a) Total dose for shipment of spent fuel discharged through 1990; assumes repository startup by 1985 .

(b) Maintain FCR, no reracking (prompt spent fuel shipment is required at many reactor plants).

(c) Expand onsite storage to a minimum of $10 / 3$ core at all reactor plants (most fuel is shipped from the reactors to the repository, avoiding need of the AFR). 
.

. 


\subsection{INTRODUCTION}

Although spent nuclear fuel has been shipped commercially for many years, a relatively modest number of shipments have been made. Spent fuel shipments from reactors are expected to increase substantially in the 1980s to away-from-reactor (AFRs) storage sites. Shipments to disposal sites (repositories) are also anticipated in the late 1980s or 1990s. Due to the large number of shipments that will be made and uncertainties about the effects of low level radiation, there has been considerable discussion of requiring that these shipments meet the "as low as reasonably achievable" (ALARA) dose reduction criteria.

To date, the ALARA principle of radiation exposure reduction has only been applied at fixed facilities. The effect on transportation systems is not known. A variety of methods have been suggested to reduce radiation exposure from spent fuel shipments. The relative value of these methods in reducing dose from spent fuel shipments and the impact on the cost, efficiency and overall safety of the system has not been determined. This study was undertaken to identify and evaluate the alternatives available for reducing the dose from spent fuel shipments.

PNL has performed this study for the Transportation Technology Center operated for DOE by Sandia Laboratories. The objective was to identify and evaluate the potential technical, procedural, and logistical methods for reducing the exposure from spent fuel transport and to evaluate the effects of these changes on safety, logistics, and costs. To accomplish these objectives, the applicable portions of the transportation and nuclear industries have been modeled in sufficient detail to examine the spent fuel logistics and the radiation dose from these shipments. Existing models were used as available, and new models were constructed where necessary. The models were used to evaluate the potential methods of dose reduction and, based on system knowledge gained, to develop other ALARA concepts.

The spent fuel logistics and dose models and the nuclear industry assumptions that were used in the analysis are presented in Section 2 . The Appendices amplify these models and present some of the intermediate results. 
The analysis of each of the various methods of dose reduction and their impact on cost and safety is presented in section 3. The comparison of the dose reduction methods is given in Section 4 .

Because there are many uncertainties surrounding future spent fuel management in the U.S., a number of possible nuclear industry operating scenarios were examined in the study. The scenarios used are somewhat hypothetical. They have been chosen to represent the range of spent fuel logistic parameters that could be encountered in the U.S. during the remainder of this century. The study focused on the time period of 1980 to 1990, when it was felt that a significant amount of spent fuel would be in transit. It was assumed that away-from-reactor storage facilities would be available in the mid-1980s, and spent fuel repositories would be in operation in the mid-1980s to early 1990s. Changes in the availability dates of these facilities would affect the results of the spent fuel transportation radiation dose calculations, but they are not expected to substantially change the conclusions of the study.

Handling spent nuclear fuel involves exposure to both gamma rays and neutrons. Neutrons present a greater biological hazard than gamma rays for the same absorbed dose. To account for this greater risk for neutrons, heal th physicists have introduced the concept of dose equivalent. It should be understood that in this report the radiation "dose" refers to "dose equivalent" with units of rem or millirem. 


\subsection{SPENT FUEL TRANSPORTATION LOGISTICS AND DOSE MODELS}

The determination of spent fuel shipping dose required an accurate description and modeling of applicable portions of the nuclear and transportation industries. This included spent fuel shipping schedules, transportation routes, shipping casks, cask loading/unloading procedures, population distributions, shipping crew activities, and shipping procedures. The model that was constructed for this study is summarized below.

Shipping schedules were determined with the Variable Site Spent Fuel Transportation Logistics Model ${ }^{(1)}$ developed at PNL. This computerized model calculates minimum-cost shipment schedules between reactor plants, AFRs and disposal sites. The data base used by the model contains the locations, storage capacities, and other pertinent information on U.S. nuclear power plants in operation or under construction and planned for startup by 1990. Table 2.1 lists the installed capacity assumed in the shipment schedule calculations.

TABLE 2.1 Installed Nuclear Electric Generation Capacity Used in the-Study

\begin{tabular}{cc}
$\begin{array}{c}\text { Study period } \\
(y r)\end{array}$ & $\begin{array}{c}\text { Installed } \\
\text { Capacity }\end{array}$ \\
\cline { 2 - 3 } 1980 & 73,000 \\
1982 & 97,000 \\
1984 & 133,000 \\
1986 & 159,000 \\
1988 & 181,000 \\
1990 & 193,000
\end{tabular}

The study assumes spent fuel is shipped from reactor plants (when necessitated by insufficient onsite storage capacity) to a privatelyoperated away-from-reactor storage facility (AFR) in the Midwest and/or to two government-operated AFRs; one located in the Southeast which becomes 
operational in 1983 and the other located in the Northwest which becomes operational in 1985. One spent fuel repository (a disposal site) located in the Southwest was assumed to begin operation in 1990 (1985 for the completed fuel cycle comparison). The government AFRs would accept fuel aged greater than 1 year; the repository would accept fuel aged greater than $61 / 2$ years. (2) The private AFR is assumed to receive any fuel not acceptable for storage at other sites. Storage cost was assumed to be lowest at the reactor plants, higher at the government AFRs and still higher at the private AFR. Disposal cost at the repository was a fixed fee. Shipping costs were included on a per ton-mile basis for both truck and rail (See Section 3.7). The maximum receiving capacity of the AFRs and repository was set at 3000 MTHM(a) /year. Each of these facilities has a limitation on cask handling capacity (900 MTHM/year for truck casks, 2100 MTHM/year for rail casks) requiring a $30 / 70$ truck/rail ratio when receiving spent fuel at maximum capacity. The nuclear and transportation industry characteristics used in this analysis are summarized in Table 2.2. The logistics analysis is further described in Appendix A.

The cask designs used in this study were the NFS-4 (truck) and NLI 10/24 (rail). The reference cask specifications are listed in Table 2.3. To model the cask dose rates at the pertinent dose points for all fuel ages in transit, a shielding analysis of these casks was done (see Appendix $B)$. The cask parametric analysis assumed the identical design technology (shield material configurations, etc.) as the NFS-4 and NLI 10/24. Only dimensions (interior, exterior, and shield thicknesses) were varied. The results of the shielding analysis were incorporated in the population exposure model discussed below.

The population exposure model calculates, for both truck and rail shipments, the dose to: residents along the path of the shipment, travelers enroute (moving in the same and opposite directions), bystanders at truck stops and sidings, truck and rail crews, and the cask loaders and (a) MTHM - Metric Tons of Heavy Metal (the uranium and its reaction products
in the spent fuel). 
TABLE 2.2 Spent Fuel Logistics Conditions

Study Period:

1980 to 1990

\section{Reactors:}

Reactors in operation, under construction or planned

Onsite spent fuel storage cost < AFR storage

Case 1: Full core reserve, no rerack

Case 2: No full core reserve, no rerack

Case 3: Full core reserve, all reactors reracked to $10 / 3$ cores or greater

$\underline{\text { AFRs }}$

2 Government AFRs become operational in 1983, 1985.

Receive spent fuel aged $>1$ year

Location - Southeast (1983), Northwest (1985)

Government AFR storage cost < private AFR

Maximum receiving capacity, 3000 MTHM/yr

1 private AFR, Midwest

Will receive spent fuel unstorable at reactor facilities prior to 1983 (1985)

After 1983, it will continue to receive short-cooled fuel which cannot be stored at reactor sites.

\section{Repository:}

1 repository begins operation in 1990

Location - Southwest

Accepts spent fuel aged $\geq 61 / 2$ years

Packaging at repository

Maximum receiving capacity, $3000 \mathrm{MTHM} / \mathrm{yr}$.

Fixed cost disposal

\section{Transportation:}

30/70 truck/rail split (receiving facilities capacity ratio)

Al1 shipments made in current generation casks

Truck transport cost per MTHM < rail transport cost for PWR fuel

Rail transport cost per MTHM < truck transport cost for BWR fuel 
TABLE 2.3 Reference Shipping Cask Specifications

\begin{tabular}{|c|c|c|}
\hline & NFS-4 (Truck) & NLI $10 / 24$ (Rail) \\
\hline Fuel Decay (Days-Min) & 120 & 150 \\
\hline Fuel Burnup (MWD/MTU - Ave) & 33,500 & 35,500 \\
\hline $\begin{array}{l}\text { Decay Heat (kw) } \\
\text { Max. } \\
\text { Licensed }\end{array}$ & $\begin{array}{l}11.5 \\
11.5\end{array}$ & $\begin{array}{l}97.2 \\
70\end{array}$ \\
\hline $\begin{array}{l}\text { No. of Fuel Assemblies } \\
\text { PWR } \\
\text { BWR }\end{array}$ & $\begin{array}{l}1 \\
2\end{array}$ & $\begin{array}{l}10 \\
24\end{array}$ \\
\hline $\begin{array}{l}\text { Cask Envelope, in } \\
\text { Diameter } \\
\text { Length }\end{array}$ & $\begin{array}{l}39.8 \\
214\end{array}$ & $\begin{array}{c}88 \\
204.5\end{array}$ \\
\hline $\begin{array}{l}\text { Cask Weight, } 1 \mathrm{~b} . \\
\text { (Loaded) }\end{array}$ & 50,059 & 193,000 \\
\hline $\begin{array}{l}\text { Shielding Material } \\
\underset{n}{n}\end{array}$ & $\begin{array}{l}\text { Lead and Steel } \\
\mathrm{H}_{2} \mathrm{O}\end{array}$ & $\begin{array}{l}\text { Lead and Steel } \\
\qquad \mathrm{H}_{2} \mathrm{O}\end{array}$ \\
\hline Cavity Coolant & $\mathrm{H}_{2} \mathrm{O}$ & $\mathrm{He}$ \\
\hline
\end{tabular}

unloaders. The general population distributions were based on 1970 U.S. census data extrapolated to the 1980-1990 study period grouped in five population densities: rural east, rural west, statistical metropolitan areas, and two special high density areas: New York and Los Angeles. A map of the five areas was overlayed on the selected routings to calculate the shipment miles for each of the five population densities. This population exposure model is described in Appendix $C$. Shipment routes were selected via the most direct interstate highway and/or major rail lines. The shipment route model is described in Appendix $D$.

Three spent fuel storage/shipping logistics cases were examined for their effect on shipment dose. They are: 
1. no reracking of storage pools allowed, FCR maintained (base case),

2. no reracking, $F C R$ not maintained, and

3. existing, and new, reactor plants are reracked to maximum capacity (typically 10/3 core or greater) but maintain FCR.

In addition, cask design parameters and routings were varied to study a variety of potential dose reduction options as discussed in Section 3.

The dose results of this study were computed and compared on two bases:

1. Completed fuel cycle - The dose was summed for all shipments of fuel projected to be discharged from the U.S. nuclear power" plants through 1990. Shipment schedules were computed as necessary to solve each logistics case.

2. Time window - The dose was summed for all fuel shipped within the time period 1980 to 1990 for each logistics case.

Eoth of these bases have merit. The completed fuel cycle base is conservative; and the results are applicable to the current shipping cask designs and industry characteristics, assuming they stay constant. The time window base gives the expected exposure in the near time frame. This base emphasizes the effect of logistics on shipment dose. There may be incentive to design the shipping system and practices for the current decade followed by future system modification to best accommodate later time periods. 


\subsection{ANALYSIS OF DOSE REDUCTION METHODS}

The radiation dose resulting from shipment of spent fuel is affected by many system parameters and management options. The most significant of these parameters and options are explored in the paragraphs below.

\subsection{SPENT FUEL STORAGE OPTIONS}

After discharge from a nuclear reactor, spent fuel is stored at the reactor site for one or more of the following reasons:

1. Cooling for a minimum of 120 days to allow shipment in a licensed cask

2. Cooling for at least 6-1/2 years (2) for geological disposal

3. Storage awaiting reprocessing, and

4. Indefinite storage for potential use as an energy resource

Spent fuel is shipped as necessary to accommodate the reactor operations. Utilities attempt to minimize cost by best utilizing their available storage facilities with a minimum of shipments. Thus, to calculate the radiation exposure due to spent fuel shipment, it was necessary to model the shipping criteria used by the industry. The three spent fuel logistics scenarios discussed in Section 2 were chosen to cover the range of possible shipment schedules during the 11-year time period 1980-1990.

Most existing nuclear power plants were designed to promptly ship spent fuel to a reprocessing facility. The moratorium on reprocessing has led to design changes such as high density "reracked" storage and/or construction of additional reactor site pool storage.

The spent fuel calculated to be shipped in the 1980-1990 time period for the three logistics scenarios is given in Table 3.1. Also given are the number of shipments by rail and truck and the average age of the fuel shipped. Appendix A presents further details (quantities shipped by year, mode and fuel age) which was required to calculate population exposure. 
TABLE 3.1 Summary of the Spent Fuel Logistic Cases

\begin{tabular}{|c|c|c|c|c|}
\hline $\begin{array}{l}\text { Cumulative } \\
\text { Discharge } \\
\text { thru } 1990 \\
\end{array}$ & $\begin{array}{c}\text { MTHM } \\
\text { Shipped } \\
\text { From Reactors } \\
1980-90 \\
\end{array}$ & \multicolumn{2}{|c|}{$\begin{array}{c}\text { Total No. of Shipments } \\
1980 \text { to } 1990 \\
\end{array}$} & $\begin{array}{c}\text { Average Age } \\
\text { of Fuel Shipped } \\
(y r)\end{array}$ \\
\hline 47,000 & 30,000 & 32,000 & 3,200 & 2.4 \\
\hline 47,000 & 14,000 & 14,000 & 1,600 & 5.7 \\
\hline 47,000 & 6,800 & 7,900 & 650 & 6.9 \\
\hline
\end{tabular}


Examination of Table 3.1 suggests that 6,800 to 30,000 metric tons of spent fuel (MTHM, the elemental weight of fuel and fuel products) will be shipped in the 11-year time period (1980 to 1990) depending on availability of onsite storage space and/or logistics policies adopted. Ultimately all 47,000 MTHM will be transported; $95 \%$ of this spent fuel will be transported twice in logistics case 1 , and $5 \%$ in logistics case 3 . In this regard, most utilities are seeking license to upgrade their onsite storage pools (by high density reracking) to roughly $10 / 3$ core (FCR plus $2-1 / 3$ cores of spent fuel), which provides spent fuel storage for about 10 years of operation. Assuming these licenses are granted (case 3 ), spent fuel shipment in the 11 year period will be a minimum; about 6,800 MTHM. In the event extensive reracking is not allowed and the reserve storage requirements are undefined, the amount of spent fuel shipped will fall between scenarios 1 and 2.

The fraction of spent fuel shipped by rail and truck were the same for all logistics scenarios. This results from economic incentives to ship PWR fuel by truck and BWR fuel by train (see Section 3.7), limited capacity at receiving facilities to handle truck shipments, and the lack of rail facilities at some reactors.

Table 3.2 presents the cumulative radiation dose from the shipment of all spent fuel discharged from reactor plants through 1990. This is the minimum exposure. This calculation assumes that a repository would be available by 1985 (required in logistics case 3). Unavailability of a repository requires shipment of this fuel to an AFR (logistics case 3 ) and a second shipment at a later date to a repository. Unavailability of the repository until 1995 would result in cumulative doses of 11,800 and 6,400 man-rem for logistics cases 1 and 3 .

Table 3.3 presents the cumulative radiation dose for spent fuel shipped in the 11-year time period 1980 to 1990. Within this time window, the logistics scenario selection has a significant effect on accumulated dose. A factor of 12 in dose exists between logistics cases 1 and 3 . The logistics case 3 in effect delays spent fuel shipment. Coupled with the anticipated growth period of nuclear power, the dose ratio between cases 1 and 3 would continue on to about the year 2000. Thereupon, the ratios of Table 3.2 would apply. 
TABLE 3.2 Cumulative Radiation Dose for Subsequent Shipment of A11 Spent Fuel Discharged From Reactors Through 1990; Three Storage/Logistics Scenarios

\begin{tabular}{|c|c|c|c|}
\hline Case & $\begin{array}{l}\text { Cumulative } \\
\text { Discharge } \\
\text { Thru } 1990 \\
\end{array}$ & $\begin{array}{c}\text { A11 Subsequent } \\
\text { Shipments, } \\
\text { (MTHM) } \\
\end{array}$ & $\begin{array}{c}\text { Minimum }(a) \\
\text { Cumulative } \\
\text { Dose } \\
\text { (man-rem) } \\
\end{array}$ \\
\hline 1. FCR, no rerack & 47,000 & 92,000 & 11,600 \\
\hline 2. No reserve, no rerack & 47,000 & 80,000 & 5,500 \\
\hline 3. FCR, rerack to 3.3 cores & 47,000 & 49,000 & 3,400 \\
\hline
\end{tabular}

(a) Assumes a repository will begin accepting spent fuel by 1985 . 
TABLE 3.3 Public and Occupational Radiation Dose - From Shipment of Spent Fuel in the 11-year period 1980-1990; Three Storage/Logistics Scenarios

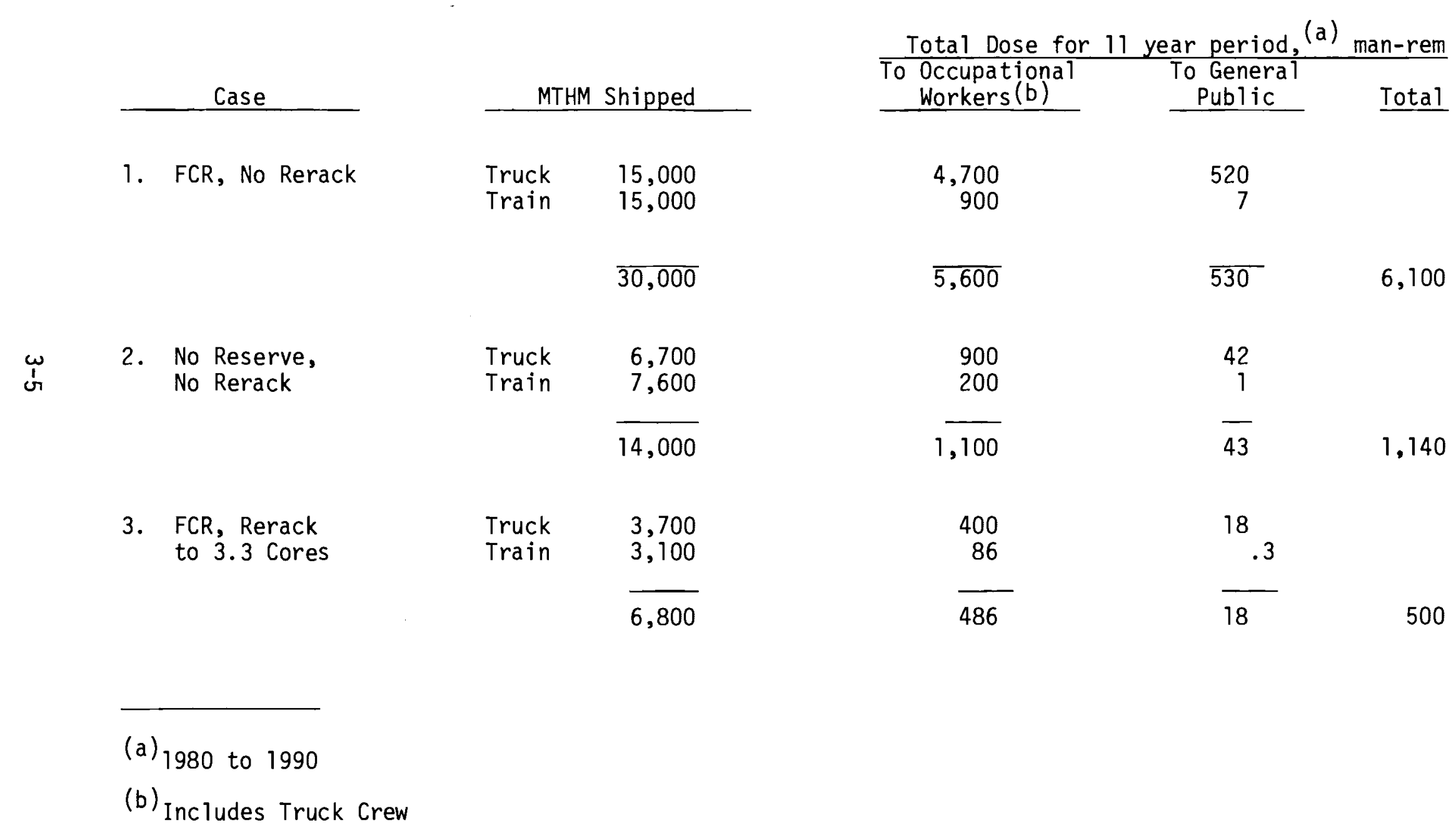


Clearly, an effective dose reduction strategy involves storing the spent fuel as long as possible at the reactor site followed by a single shipment of the spent fuel to a disposal site. (a) Taking this argument one step further, onsite spent fuel disposal (or reprocessing) would eliminate all public exposure due to transportation.

Table 3.3 also lists the distribution of shipments between truck and rail and the distribution of radiation dose between the occupational work force and the general public. Note that most of the radiation exposure associated with spent fuel shipment is accumulated by the occupational workers; a factor of 10 to 1000 over the public exposure depending on the fuel age and shipping mode (truck or rai1). Dose to the general public will be very low (1.3 man-rems for scenario 3 ).

The average truck shipment will travel in the proximity of about 100,000 people enroute: the loaders, the shipping crew, travelers along the highway, travelers and workers at rest stops or sidings, and individuals residing along the route. Table 3.4 lists the average radiation exposure to each type of individual. Individual doses to the travelers and residents are negligible; the occupational crew exposures are consistent with measurements and other time studies. $(3,4)$

Examination of Tables 3.3 and 3.4 suggests that changes in the loading and unloading procedures and facilities have potential for larger operator dose reduction than do changes in the cask external dose rate specification and/or a reduction in the number of shipments or a change in the age of the fuel shipped (see Section 3.3).

\subsection{SHIPMENT OPTIONS}

The cost of shipping spent fuel either by truck or rail is very nearly equivalent. The NFS-4 truck cask will handle 1 PWR element and 2 BWR elements and the NLI 10/24 cask handles 10 PWR elements and 24 BWR elements.

(a) Herein, disposal sites are those at which ultimate disposition of the fuel occurs (e.g., geologic repositories, reprocessing plants or some combination of retrievable storage with ultimate reprocessing). 
TABLE 3.4. Average Dose to a Person Exposed to a Spent Fuel Shipment

\begin{tabular}{|c|c|c|c|c|}
\hline \multirow[b]{2}{*}{ Logistics Case } & \multicolumn{4}{|c|}{ Average Dose/Person/Shipment (mrem) } \\
\hline & Loading Crew & Trkrs./RR Wkrs (a) & Travelers & Residents \\
\hline $\begin{array}{c}\text { 1. Truck } \\
\text { Train }\end{array}$ & $\begin{array}{r}7 \\
23\end{array}$ & $2 \times 10^{-3}$ & $\begin{array}{r}9 \times 10^{-3} \\
2 \times 10^{-2}\end{array}$ & $\begin{array}{l}<10^{-5} \\
<10^{-5}\end{array}$ \\
\hline $\begin{array}{l}\text { 2. Truck } \\
\text { Train }\end{array}$ & $\begin{array}{r}4 \\
11\end{array}$ & $4 \times \frac{7}{10^{-4}}$ & $\begin{array}{l}2 \times 10^{-4} \\
5 \times 10^{-3}\end{array}$ & $\begin{array}{l}<10^{-6} \\
<10^{-5}\end{array}$ \\
\hline $\begin{array}{l}\text { 3. Truck } \\
\text { Train }\end{array}$ & $\begin{array}{r}4 \\
11\end{array}$ & $4 \times 10^{-4}$ & $\begin{array}{l}1 \times 10^{-4} \\
4 \times 10^{-3}\end{array}$ & $\begin{array}{l}<10^{-6} \\
<10^{-5}\end{array}$ \\
\hline
\end{tabular}

(a) Truckers and railroad workers 
This minor variation is sufficient to economically favor PWR element shipment by truck and BWR elements by rail (see Section 3.7). Other factors which affect the shipping mode choice are: existence of a rail spur to the reactor plant, availability of casks, and the unloading capacity at the AFR or disposal site (1imited facilities for truck casks).

The radiation dose for shipment by rail and truck is compared in Table 3.5 based on the shipment logistics mix of cases 1 through 3 . Shipment by rail results in lower occupational and public exposures by factors of about 5 and 50 respectively on a per ton shipped basis. Lower exposures for rail shipment are due to the lower number of required shipments (approx. $1 / 10)$ the lower number of people (travelers) contacted enroute, and the transport crew being located farther from the cask.

\subsection{FUEL AGE}

The dose equivalent rates at the exterior (side mid point, centerline) of the NFS-4 and NLI 10/24 casks containing spent PWR fuel are plotted in Figure 3.1 versus fuel age. The dose rates are mixed gamma and neutron; approximately $10 \%$ neutron for short cooled fuel and 50\% neutron for long cooled (>3 year) fuel. This is described in detail in Appendix B. Measurements of actual shipments confirm these values.

With existing cask designs, shipments of older fuel ( $>3$ years) have dose rates roughly $1 / 7$ the dose rates of short cooled shipments. The average fuel age will change with various shipping scenarios (see Appendix A). The average dose per shipment (man-rems/MTHM shipped) was plotted (Figure 3.2) against the average fuel age in each of the three shipping scenarios.

Public exposure is directly proportional to cask surface dose rate. Occupational exposure is somewhat independent of fuel age; e.g. cask loading and unloading dose and the truck crew dose (added shielding is used to limit truck cab dose rate to $2 \mathrm{mrem} / \mathrm{hr}$ ). Occupational exposure is predominant and varies with fuel age by about a factor of 2.5. Thus, while fuel age can affect cask surface dose rate by as much as a factor of 7 , actual variation in exposure will be limited to about 2.5 as seen in Figure 3.2. 
TABLE 3.5 Radiation Dose for Truck and Rail Shipment

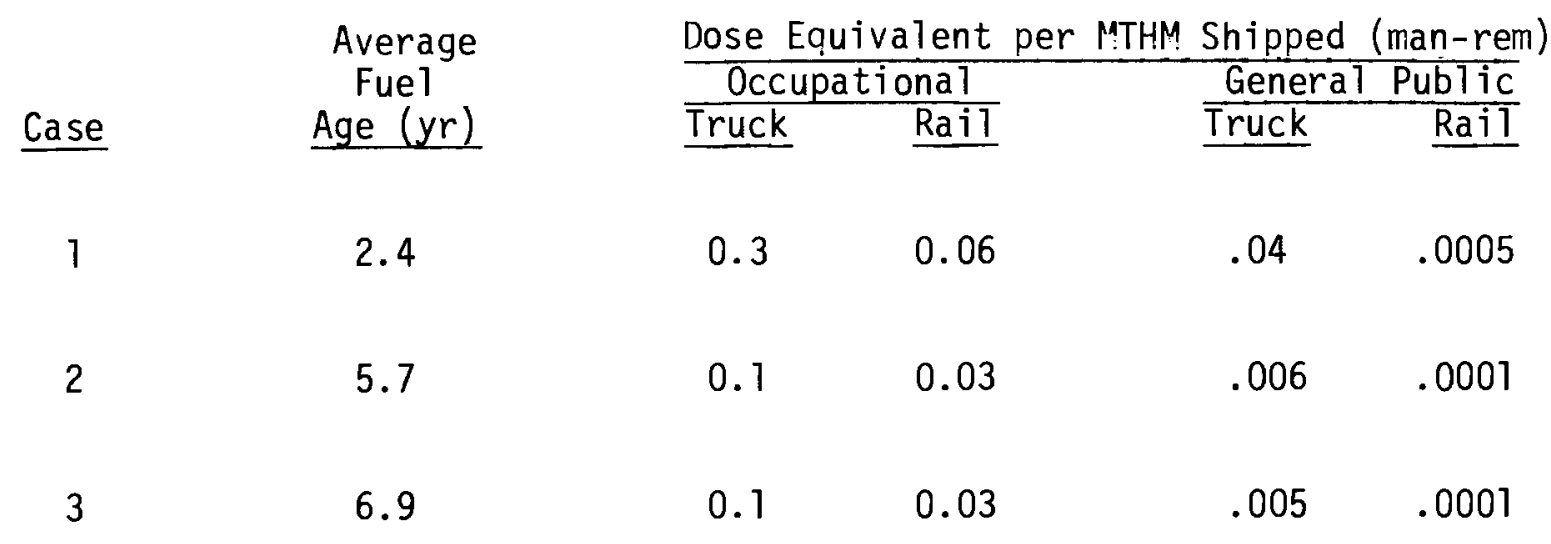




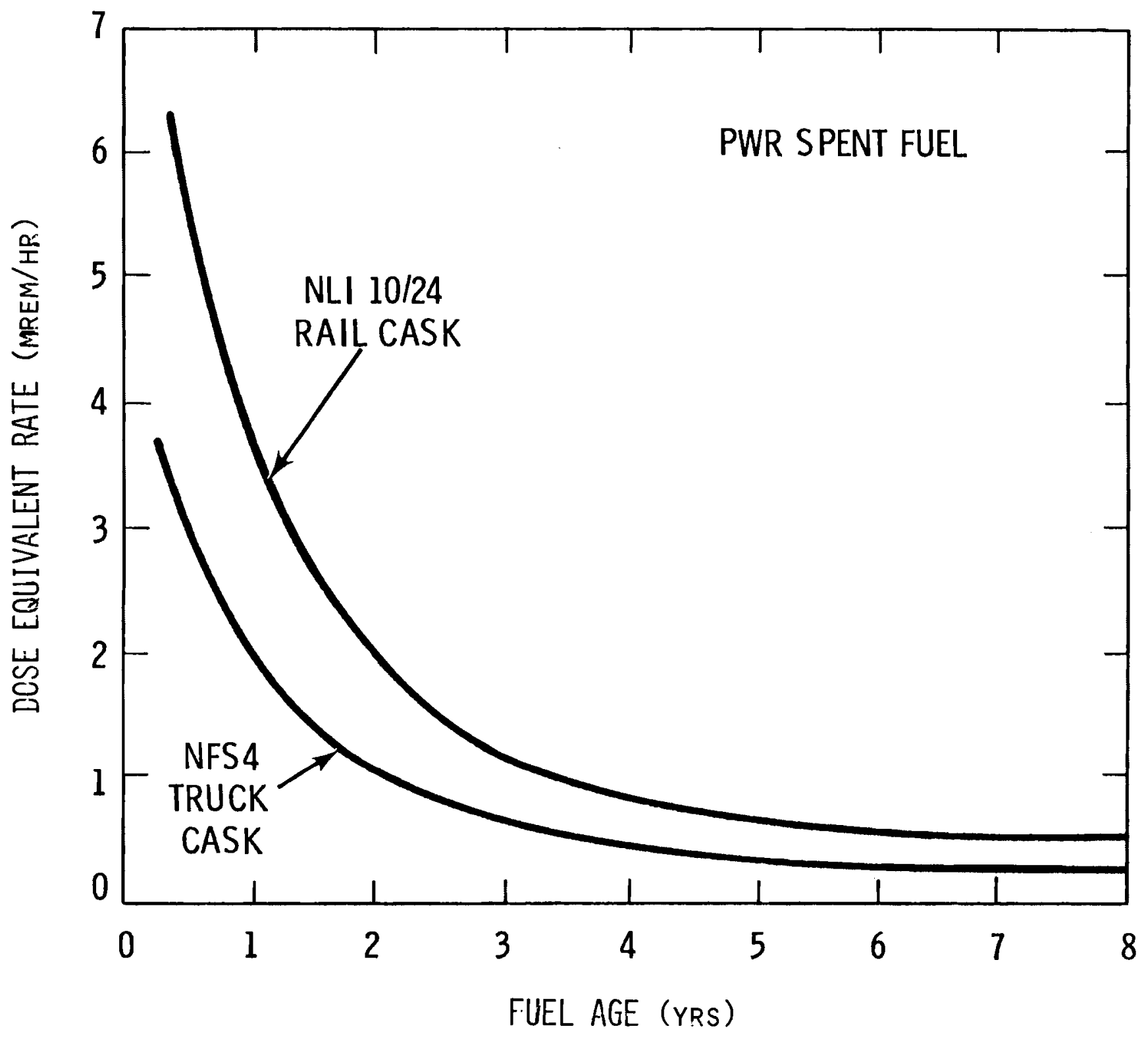

FIGURE 3.1 NFS-4 and NLI 10/24 Dose Rates

$10 \mathrm{ft}$ From Cask Centerline 


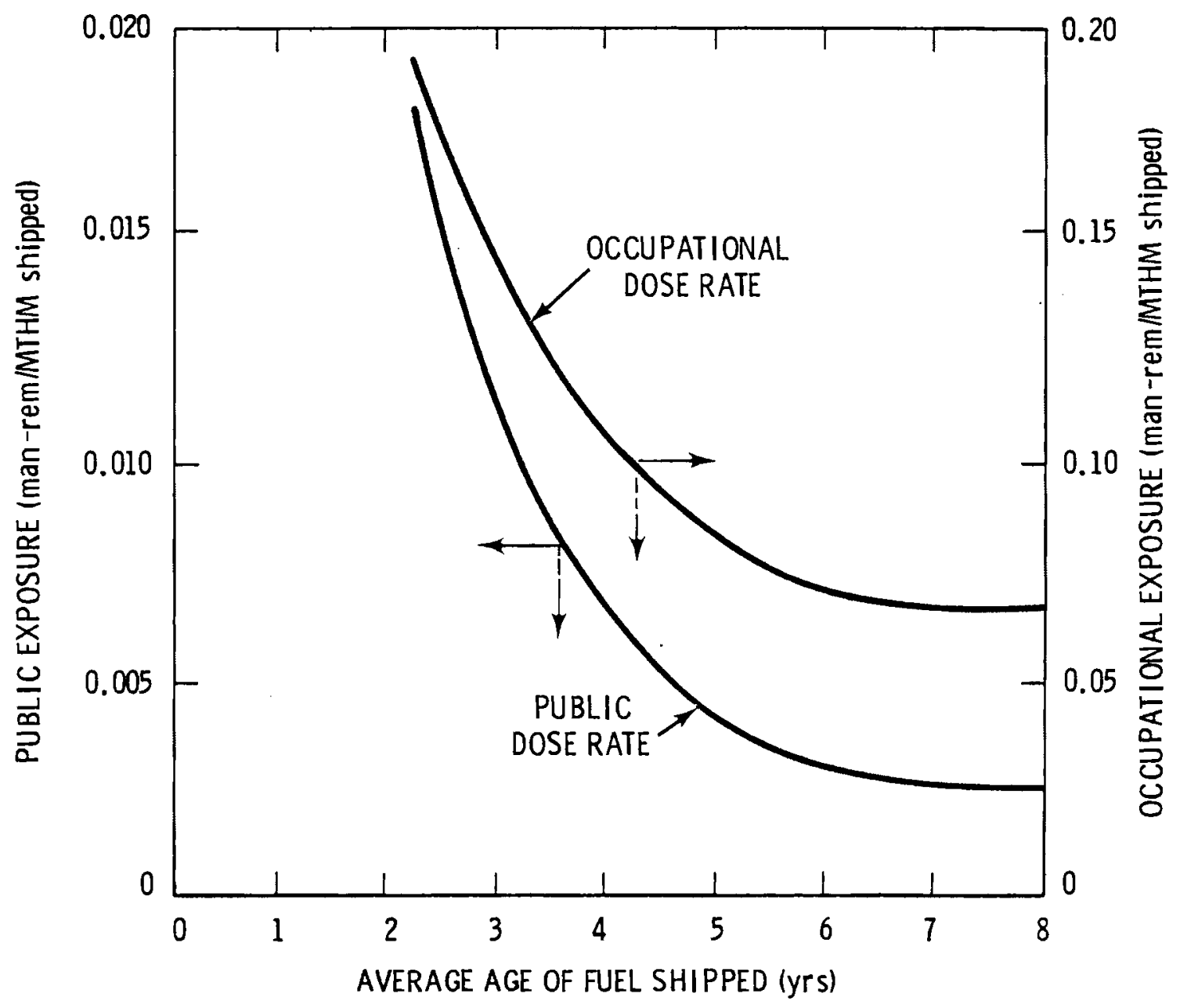

FIGURE 3.2 Public and 0ccupational Dose Rate for Spent Fuel Shipment vs. Average Fuel Age 


\subsection{CASK DESIGN}

Three aspects of cask design affect population exposure: 1) shielding thickness, 2) the loading/unloading system, and 3) the cask capacity. These design aspects are interrelated; that is, within the legal weight constraints of truck transport ( 25 tons) and rail transport ( 100 tons). Dose rate reduction would appear to require thicker shields, greater fuel age, and less spent fuel per shipment. However, less fuel per shipment correspondingly increases the number of shipments and the dose.

Table 3.6 1ists the population dose due to shipping 5-year-old fuel in casks of various dose specifications. A 5-year minimum fuel age shipment constraint would be roughly equivalent to the schedule of logistics case 3 (Table A.3); thus this schedule was used in the comparison. The cask dose rate specifications examined in Table 3.6 are:

1. $10 \mathrm{mrem} / \mathrm{hr}$ a $6 \mathrm{ft}^{(\mathrm{a})}$ for short-cooled fuel. This is the design specification for the NFS-4 and NLI 10/24 casks. These casks have a $6 \mathrm{ft}$ dose rate of 0.3 and $0.6 \mathrm{mrem} / \mathrm{hr}$ when loaded with 5 -yearold fuel (see Figures C.1 and C.2). Note that this is the standard case 3 (i.e., the doses are the same as case 3, Table 3.3.)

2. $10 \mathrm{mrem} / \mathrm{hr}$ \& $6 \mathrm{ft}$ for 5 -year-old fuel.

3. $1 \mathrm{mrem} / \mathrm{hr}$ \& $6 \mathrm{ft}$ for 5 -year-old fuel.

Casks conforming to these specifications would be designed to accommodate the maximum number of fuel elements within the weight limitations discussed above. Casks capacities used in this comparison are listed in Table 3.7. (Cask capacity, fuel age and dose specification parameters examined in this study are discussed in Appendix F.)

Examination of Tables 3.6 and 3.7 indicates that casks designed for aged fuel will accommodate larger fuel loads. The number of train shipments will be reduced; however, the dose per shipment will increase (see specification 1 above ${ }^{(b)}$ ).

\footnotetext{
(a) From the vehicle surface.

(b) The dose reduction advantage of shipping 5-year (and older) spent fuel in the NFS-4 and NLI 10/24 casks is examined in Figure 3.2.
} 
TABLE 3.6 Effect of Cask Design on Population Dose (Case 3, FCR, Rerack to $31 / 3$ Core)

Cask Design

1) NFS-4 and (c)

NLI $10 / 24$

$\begin{array}{ll}\begin{array}{l}\text { Number of } \\ \text { Shipments }\end{array} & \text { Dose for } 11 \text { year Period (a) (man-rem) } \\ \text { Occupational General } \\ \text { and Mode } \\ \text { Worl:ers }(b)\end{array}$

7900 Truck $\quad 400$

650 Train $\quad 86$

$18 \quad 418$

$.3 \quad 86$

500

2) 5-year-old fuel, $10 \mathrm{mrem} / \mathrm{hr}$ \& $6 \mathrm{ft}$. (d)

7800 Truck

320 Train

1640

130

\begin{tabular}{rr}
210 & 1850 \\
2 & 132 \\
\hline
\end{tabular}

1980

3) 5-year-old fuel $1 \mathrm{mrem} / \mathrm{hr}$ \& $6 \mathrm{ft}$.
7900 Truck

380 Train
420

50
$24 \quad 444$ $.3 \quad 51$

\footnotetext{
(a) Study period, 1980-1990

(b) Cask loading crews and truck drivers

(c) Current specification - $10 \mathrm{mrem} / \mathrm{hr} \odot 6 \mathrm{ft} ., 120$ and 150 day min. fuel age.

(d) $6 \mathrm{ft}$. from vehicle surface.
} 
TABLE 3.7 Cask Capacity and Weight vs.

Dose and Fuel Age

\section{Cask}

Specification

1) $10 \mathrm{mrem} / \mathrm{hr}$ a $6 \mathrm{ft}$ (b)

short cooled fuel

Truck

Rail

2) $10 \mathrm{mrem} / \mathrm{hr}$ \& $6 \mathrm{ft}$.

5-year-old fuel

Truck

Rail

3) $1 \mathrm{mrem} / \mathrm{hr}$ \& $6 \mathrm{ft}$

5-year-old fuel

Truck

Rail

\author{
Cask Capacity \\ Elements (PWR/BWR)
}

Cask Weight $(a)$

loaded tons
$1 / 2$

$10 / 24$

$1 / 3$

$21 / 48$

25

95

25

96.5
$1 / 2$

$15 / 41$
23

99

\footnotetext{
(a) 5-year fuel age cases are approximate.

(b) Current specification for NFS-4 (Truck Cask) and NLI 10/24 (Rail Cask). Fuel age 120 and 150 days.
} 
The dose within the study period will be essentially the same with the $1 \mathrm{mrem} / \mathrm{hr}$ specification; however, the number of train shipments will be reduced, and truck shipments will go at a lower weight. Thus the incentive (based on the specifications examined) for cask redesign for 5-year fuel is primarily economic. In the event 5-year-old spent fuel casks are contemplated, ALARA considerations would favor the $1 \mathrm{mrem} / \mathrm{hr}(\mathrm{a})$ dose specification. This study assumes that cask redesign would not affect ratio of quantities shipped by rail and truck. If this were not the case, this conclusion would change somewhat.

\subsection{ROUTING OPTIONS}

The possibility of reducing population exposure by routing the shipment around highly populated regions has been examined. Table 3.8 ists the population exposure for shipment of spent fuel from four reactor sites to their respective AFRs using direct and alternate routing. (b) The alternate routing reduces exposure to the residents and travelers enroute by about $1 / 3$, but due to the increased mileage, the increased driver and truck stop dose more than offsets the reductions.

The alternate routes were selected to totally bypass the Atlantic seaboard and the Los Angeles areas. As with the primary route selection, the alternate routes followed the interstate highway system to the maximum possible extent. Note that the alternate routing for shipment from Three Mile Island to the southeast AFR results in lower miles and a minor reduction in total dose. However, the alternate routing involves irregular terrain and would be a second choice to truckers.

Rerouting for accident and safeguards considerations has been adopted. (5) The above considerations suggest this practice will increase the overall exposure.

(a) Dose at 6 feet from the vehicle surface.

(b) Shipment doses from the eastern plants in this example are significantly lower than the shipment dose from the western plant. This analys is was done for logistics Case 1 (plants with minimum onsite storage must ship short-cooled fuel). The three eastern plants (Table 3.5.1) have large spent fuel pools and ship only aged fuel ( $>5$ years) while Palo Verde (Arizona) ships short-cooled fuel ( 1 and 2 years old). 
TABLE 3.8 Spent Fuel Shipment Dose: Effect of Rerouting Around Metropolitan Areas (Case 1; FCR, No Rerack, Truck Shipment)

\begin{tabular}{|c|c|c|c|c|c|c|}
\hline & Shipping & & & ipment Dose & (man-rem) & \\
\hline Origin/Destination & $\begin{array}{c}\text { Distance } \\
(\mathrm{km})\end{array}$ & $\begin{array}{l}\text { Residents } \\
\text { Enroute }\end{array}$ & $\begin{array}{c}\text { Travelers } \\
\text { Enroute }\end{array}$ & $\begin{array}{l}\text { Bystanders } \\
\text { at Stops }\end{array}$ & Truckers & Total \\
\hline
\end{tabular}

Indian Point (north

of NYC), to south

east AFR

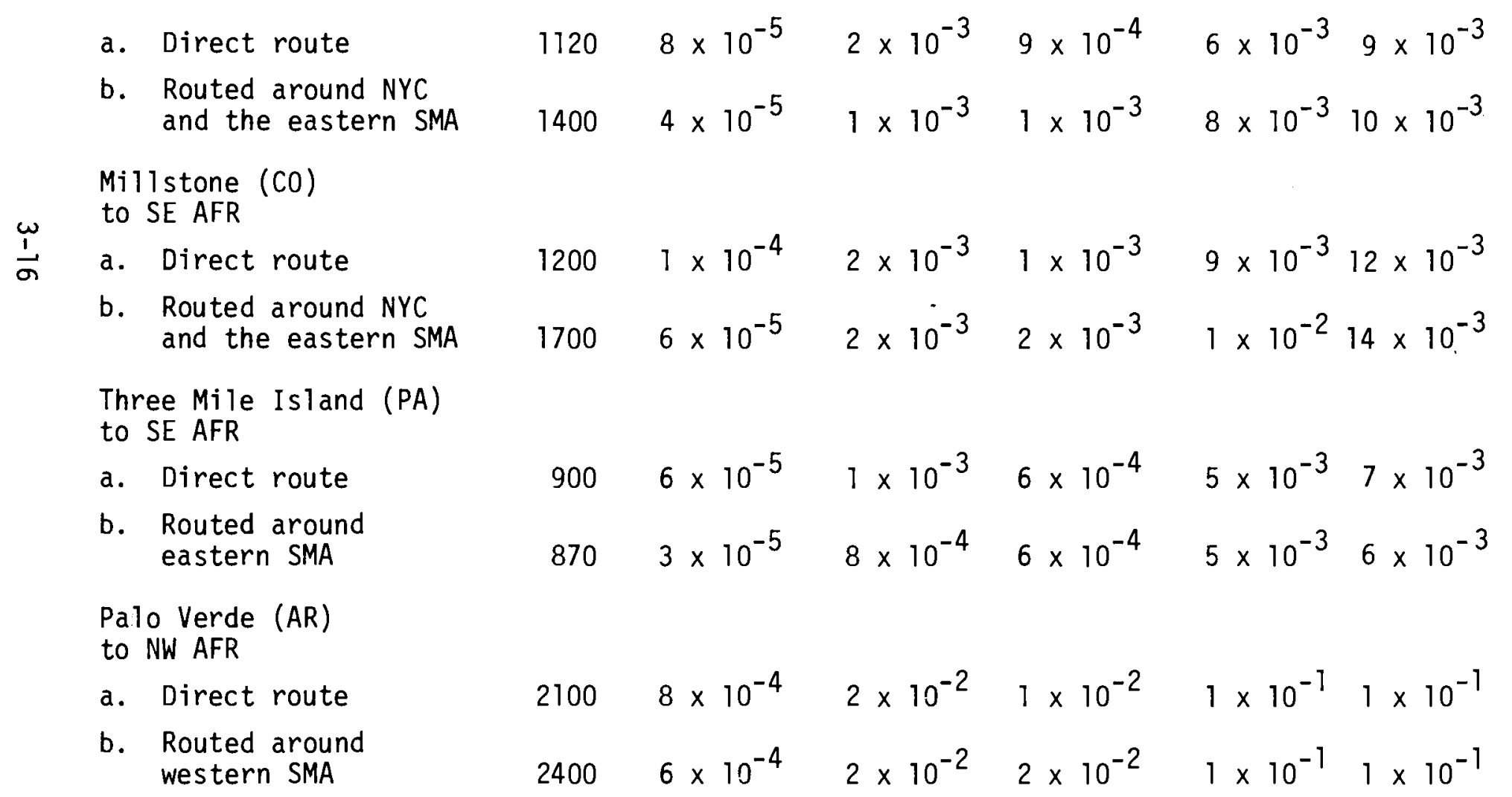


TABLE 3.10 Conversion Factors for Population Dose:

Maximum Number of Health Effects

\section{Organ of \\ Reference}

Lung

Thyroid

Bone

Total Body

\section{Estimated Excess Cancer Deaths}

\begin{tabular}{cc} 
Ber $10^{6}$ man-rem \\
\hline $16-110$ & 50 \\
$1-15$ & 5 \\
$2-17$ & 6
\end{tabular}

$50-450 \quad 200$

\section{$3.7 \quad$ COST}

The projected industry cost for shipping spent fuel during the study period 1980 to 1990 is examined in Table 3.11. Shipping costs are given for each of the logistics and cask design cases which have been considered above.

Shipping costs are directly related to the number of shipments. Thus, spent fuel storage concepts which eliminate a shipment leg (e.g., the AFR to the repository shipment) reduce shipping cost. Logistics Case 3 is thus preferred for both economic and dose reasons.

Section 3.4 points out that dose reduction can be accomplished by designing shipping casks for a minimum fuel age of five years. Use of a $1 \mathrm{mrem} / \mathrm{hr}$ or a $10 \mathrm{mrem} / \mathrm{hr}$ dose specification allows larger cask loads. The costs are correspondingly lower as indicated in Table 3.11. Note that the lowest dose is achieved with cask design \#3 (1 mrem/hr o $6 \mathrm{ft}$., 5-yearold fuel). With cask design \#3, each shipment travels at a somewhat higher dose rate, but the increased cask capacity reduces the number of shipments and correspondingly the dose and the cost. With cask design \#3, the public dose increases slightly, but the occupational dose is reduced more significantly. Comparing cask cases 2 and 3 for the 1980 to 1990 time period 


\subsection{ACCIDENTS}

Accidental injuries and fatalities not related to radiological effects contribute a significantly greater portion of the hazard of spent fuel transport than does the direct radiation dose. This issue is examined in Table 3.9 where the potential fatalities for spent fuel transport attributable to accident trauma, accidental radioactive material release and direct radiation exposure are compared. The dominating hazard is accident trauma. The health effect conversion factors for the radiation induced fatalities are EPA(6) values which were based on $\operatorname{BEIR}^{(7)}$ recommendations. These conversion factors are given in Table 3.10.

TABLE 3.9 Potential Fatalities Attributable to Spent Nuclear Fuel Transport

Transportation accident fatalities accidental nuclear Logistics Case

1. Shipments, 1980-1990

Al 1 cumulative shipments

3. Shipments, 1980-1990

Al1 cumulative shipments
2.7

8.3

$8 \times 10^{-3}$

$3 \times 10^{-5}$

$2 \times 10^{-4}$
Potentia 1 non-accidental radiation exposure fatalities

The trauma deaths are based on accident statistics. The radiation deaths are based on pessimistic estimates (see Table 3.10). The supporting accident data are given in Appendix G. 
TABLE 3.11 Projected Nuclear Industry Spent Fuel Shipping Costs (1976)

$\frac{\text { Costs and dose for time period 1980-1990 }}{\text { MTHM }}$

Shipped Dose (man-rem) Cost (\$M)
Costs and dose for subsequent shipment of all fuel discharged through 1990

MTHM Total Total

Shipped Dose (man-rem) Cost (\$M)

Logistics Case 1

Cask Design

$30,000 \quad 6,100$

350

91,500

11,600

1,070

Logistics Case 3

$\frac{\omega}{\omega}$

$\begin{array}{lrr}\text { Cask Design } 1^{(a)} & 6,800 & 500 \\ \text { Cask Design } 2^{(b)} & 6,800 & 2,000 \\ \text { Cask Design } 3^{(c)} & 6,800 & 500\end{array}$

73

49,300

3,400

580

55

49,300

13,500

430

58

49,300

3,340

460

(a) Short-Cooled fuel, $10 \mathrm{mrem} / \mathrm{hr}$ e $6 \mathrm{ft}$ from vehicle surface.

(b) 5 -year old fuel, $10 \mathrm{mrem} / \mathrm{hr}$ a $6 \mathrm{ft}$ from vehicle surface.

(c) 5 -year old fuel, $1 \mathrm{mrem} / \mathrm{hr}$ \& $6 \mathrm{ft}$ from vehicle surface. 
provides a cost factor which is attributable to dose reduction. The cost difference between these cases is three million dollars while the dose difference is 1500 man-rem. The dose cost between these cases is about $\$ 2000 /$ man-rem.

The data of Table 3.11 are based on 1976 shipping tariffs for the NLI 10/24 rail cask and the NLI $1 / 2$ truck cask ${ }^{(1)}$ (most recently constructed versions of the NFS-4). These tariffs are given in Table 3.12. Fixed costs are per round trip and are based on the summation of cask use charges for the number of load/unload days and a minimum transportation charge. Mileage costs are the summation of per mile transportation tariffs and the daily cask use charge divided by miles traveled per day; 400 miles per day for trucks and 250 miles per day for trains. Transportation charges for trucks were obtained from the 1976 Tristate Motor Carrier Tariffs (Item No. 4500A). Rail charges were estimated from Reference 8.

TABLE 3.12 Shipping Tariffs ${ }^{(1)}$ (1976)

\begin{tabular}{|c|c|c|c|c|}
\hline & $\begin{array}{r}\text { Fixe } \\
\langle \$ 1 \\
\end{array}$ & $\begin{array}{l}\text { Cost } \\
\text { THM) }\end{array}$ & $\begin{array}{r}M i 1 \\
(\$ / M\end{array}$ & $\begin{array}{l}\text { e Cost } \\
\text {-mile) }\end{array}$ \\
\hline & PWR & $B W R$ & PWR & BWR \\
\hline NFS- 4 & 5370 & 6500 & 5.90 & 7.10 \\
\hline$-10 / 24$ & 4200 & 4200 & 7.60 & 7.60 \\
\hline
\end{tabular}




\subsection{COMPARISON OF DOSE REDUCTION METHODS}

Tables 4.1 and 4.2 compare the changes in population dose, in shipping cost, and in postulated shipping fatalities which would occur due to changes in spent fuel logistics and shipment technology. Table 4.1 compares logistics cases 1 and 3 . It is clear that policy decisions on spent fuel storage and logistics have a major impact on shipment dose. A factor of 12 in shipment dose exists between these logistics cases in the time period 1980 to 1990. For the completed fuel cycle, this ratio is 3 . Table 4.2 lists the differences in dose that occur when the various technical options are applied and compared to logistics case 1. Efforts to improve the occupational exposure are particularly promising. The indicated level of dose reduction could be achieved by the combination of a superior cask closure system, el imination of contact decontamination procedures, and additional head end and/or truck cab shielding.

Redesign of fuel casks to accommodate 5 -year-old fuel at the current dose rate specification of $10 \mathrm{mrem} / \mathrm{hr}$ at $6 \mathrm{ft}$ will raise the transportation dose. Current casks transport 5-year-0ld fuel at about $0.5 \mathrm{mrem} / \mathrm{hr}$ at $6 \mathrm{ft}$. Redesign of casks to $10 \mathrm{mrem} / \mathrm{hr}$ at $6 \mathrm{ft}$ will increase the truck cask capacity to $1 / 3$ (PWR/BWR) elements and the train cask capacity to $21 / 48$. The number of shipments would fall by a factor of 2, but the transportation dose would still rise. The dose increase given in Table 4.2 is based on a fixed logistics case (i.e., the shipping split between truck and rail was based on the current generation cask economics). On the basis of economics alone, redesigned casks would favor rail transport for all shipments. This could substantially reduce the exposure for this case. Independent of economics, a transportation dose rate reduction would be achieved by cask design for 5-year-old fuel at $1 \mathrm{mrem} / \mathrm{hr}$ at $6 \mathrm{ft}$. With this option, the cask capacities are $1 / 2$ and $15 / 41$, about the $20 \%$ reduction in capacity with a factor of 10 reduction in dose rate. 
Significant public dose reduction over that obtained by current generation casks is unlikely. Public dose is near the low optimum (on trade-off between cask capacity and dose rate) within the economic constraints of case 1 logistics. Even though the public dose is small, revised economics to account for cask redesign would also produce additional dose reciuction (for the 5 -year, $1 \mathrm{mrem} / \mathrm{hr}$ cask).

Rerouting to avoid population centers shows no potential for overall dose reduction.

TABLE 4.1 Logistics Policy Comparison: Spent Fuel

Shipping Dose, Costs and Potential Casualties

Shipments in time period

$\frac{1980 \text { to } 1990}{\text { Dose Cost Potential }}$

(man-rem) (\$M) Casualties
Subsequent shipment of spent fuel discharged through 1990 Dose Cost Potential (man-rem) (\$M) Casualties

Logistics

Case 1

6,100

350

4

11,600

1070

10

Logistics

Case 3

500

73

.6

3,400

580

4

Difference $\overline{5,600} \quad \overline{247}$

3.4

8,200

$\overline{490}$

6 
TABLE 4.2 Technology Options (Compared to Logistics Case 1, 1980-1990)

\begin{tabular}{lcc}
$\begin{array}{l}\text { Dose Change } \\
\text { for 11-yr period }\end{array}$ & $\begin{array}{c}\text { Cost } \\
\text { Change }\end{array}$ & $\%$ Change in \\
$1980-90$ (man-rem) & Shipment \\
\hline
\end{tabular}

\begin{tabular}{|c|c|c|c|}
\hline \multicolumn{4}{|l|}{ Improved Occupational } \\
\hline \multicolumn{4}{|l|}{$\begin{array}{l}\text { Cask Design Change } \\
\text { For: }\end{array}$} \\
\hline Reduced exposure & -10 & Nu11 & Nut 1 \\
\hline $\begin{array}{l}\text { 5-year-old fuel } \\
\text { a current dose } \\
\text { rate specification }\end{array}$ & +1500 & -18 & +30 \\
\hline $\begin{array}{l}\text { 5-year-old fuel } \\
\text { o } 1 \mathrm{mrem} / \mathrm{hr} \text { o } 6 \mathrm{ft}\end{array}$ & -9 & -15 & -10 \\
\hline Rerouting & $\begin{array}{l}\text { Smal1 } \\
\text { Increase }\end{array}$ & $\begin{array}{c}\text { Sma11 } \\
\text { Increase }\end{array}$ & $\begin{array}{c}\text { Sma11 } \\
\text { Increase }\end{array}$ \\
\hline
\end{tabular}




\section{REFERENCES}

1. W. B. Andrews et al., Pacific Northwest Laboratory (PNL) Spent Fuel Transportation and Handling Facility Models, PNL-3105, Pacific Northwest Laboratory, Richland, Washington. September 1979.

2. Technology for Commercial Radioactive Waste Management. DOE/ET-0028, Volume 5, Department of Energy, Washington, D.C., May 1979.

3. R. T. Anderson et. al., "Operational Assessment of the NLI 10/24 Spent Fuel Rail Casks." AGNS-1040-1.1-29, Allied-General Nuclear Services, Barnwell, South Carolina, August 1978.

4. R. T. Anderson, "Light Water Reactor Spent Fuel Transportation Systems". AGNS-1040-1.3-47, Allied-General Nuclear Services, Barnwel1, South Carolina, October 1978.

5. "Physical Protection of Shipments of Irradiated Reactor Fuel - Interim Guidance." NUREG-0561, Nuclear Regulatory Commission, Washington, D.C.

6. "Environmental Radiation Dose Commitment: An Application to the Nuclear Power Industry," EPA 520/4-73-002, M.S. Environmental Protection Agency, Washington, D.C., June 1974.

7. "The Effects on Population of Exposure to Low Levels of Ionizing Radiation," Report of the Advisory Committee on the Biological Effects of Ionizing Radiation, National Academy of Science, November 1972.

8. R. E. Rhoads et. al., A Safety and Economic Study of Special Trains for Shipment of Spent Fuel. BNWL-2263, Pacific Northwest Laboratory, Richland, Washington, December 1977. 
APPENDIX A

SPENT FUEL LOGISTICS MODEL 


\section{SPENT FUEL LOGISTICS MODEL}

Between the reactor plants, the away-from-reactor (AFR) storage facilities, and the spent fuel disposal sites is a finite material handling system consisting of handling equipment, truck and rail transport casks, and truck and rail right-of-ways. Recognizing that spent fuel shipping will be constrained by the capacity of these systems, PNL developed a variable site spent fuel transportation logistics model (VSM) $(1,2,3)$ which calculates minimum cost shipping schedules. The VSM model was used in this study.

The VSM consists of a reactor data base (conforming to the Nuclear News "World List of Reactors" ${ }^{(4)}$ and the spent fuel inventory projections of $\mathrm{OWI}^{(5)}$ ), a transportation logistics model (constrained for this study as identified in Table 2.2), and a network optimization algorithm. The VSM is summarized in Figure A.1. The spent fuel transportation network for this study is summarized in Figure A.2. Based on the shipping system conditions and storage scenarios (Table 2.2) selected for this study, the VSM calculated the 1980 to 1990 shipping schedules given in Tables A.1 to $A .3$ and the fuel age distribution in transport given in Table A.4.

The solution methodology employed by VSM is mathematical programming implemented by a minimum cost primal network algorithm. The algorithm is interfaced on an interactive computer graphics system which allows the user to examine and modify geographic data relative to a reference display map of the United States. The locations of a 11 currently operating, under construction, and planned light water nuclear reactors (to 1990) within the contiguous United States are displayed on the map by reactor type (BWR, PWR). The reactor locations, spent fuel discharge schedule, and other pertinent information on each reactor are located in a reactor data base. The user-selected AFR and spent fuel disposal sites and other user inputs, together with information from the reactor data base, are translated into a problem structure describing the spent fuel distribution network. The network computer code then produces the minimum cost solution to the distribution problem reflecting the current user requirements and hypotheses under examination. 
TABLE A. 1 Spent Fuel Shipments - Case 1, FCR, No Rerack

\begin{tabular}{lrrrrr} 
& \multicolumn{2}{c}{$\begin{array}{c}\text { Number of } \\
\text { Shipments }\end{array}$} & \multicolumn{2}{c}{ MTHM Shipped } \\
$\underline{\text { Date }}$ & $\underline{\text { Truck }}$ & $\underline{\text { Rail }}$ & $\underline{\text { Truck }}$ & $\frac{\text { Rail }}{473}$ \\
1980 & 965 & 100 & 454 & 473 \\
1981 & 962 & 125 & 452 & 591 \\
1982 & 1,626 & 136 & 764 & 643 \\
1983 & 2,028 & 123 & 953 & 582 \\
1984 & 1,974 & 236 & 928 & 1,116 \\
1985 & 3,907 & 274 & 1,836 & 1,296 \\
1986 & 3,911 & 315 & 1,838 & 1,489 \\
1987 & 3,913 & 372 & 1,839 & 1,759 \\
1988 & 3,909 & 436 & 1,837 & 2,061 \\
1989 & 3,920 & 516 & 1,842 & 2,440 \\
1990 & $\underline{4,658}$ & $\underline{535}$ & $\underline{2,189}$ & $\underline{2,529}$ \\
\hline TOTALS & 31,773 & 3,168 & 14,932 & 14,979
\end{tabular}


TABLE A.2 Spent Fuel Shipments - Case 2, No FCR, No Rerack

\begin{tabular}{|c|c|c|c|c|}
\hline \multirow[b]{2}{*}{ Date } & \multicolumn{2}{|c|}{$\begin{array}{l}\text { Number of } \\
\text { Shipments }\end{array}$} & \multicolumn{2}{|c|}{ MTHM Shipped } \\
\hline & Truck & Rail & Truck & Rail \\
\hline 1980 & 243 & 8 & 114 & 38 \\
\hline 1981 & 333 & 10 & 157 & 47 \\
\hline 1982 & 467 & 23 & 219 & 46 \\
\hline 1983 & 437 & 42 & 205 & 199 \\
\hline 1984 & 581 & 77 & 273 & 364 \\
\hline 1985 & 1,005 & 90 & 472 & 426 \\
\hline 1986 & 2,157 & 103 & 1,014 & 487 \\
\hline 1987 & 2,119 & 167 & 996 & 790 \\
\hline 1988 & 2,043 & 296 & 960 & 1,399 \\
\hline 1989 & 2,105 & 387 & 989 & 1,830 \\
\hline 1990 & $\underline{2,724}$ & 419 & 1,280 & 1,981 \\
\hline TOTALS & 14,214 & 1,622 & 6,679 & 7,607 \\
\hline
\end{tabular}


TABLE A.3 Spent Fuel Shipments - Case 3, FCR, Rerack to 10/3 Cores

\begin{tabular}{lrrrrr} 
& \multicolumn{2}{c}{$\begin{array}{c}\text { Number of } \\
\text { Shipments }\end{array}$} & \multicolumn{2}{c}{ MTHM Shipped } \\
Date & Truck & $\underline{\text { Rai1 }}$ & Truck & Rail \\
\hline 1980 & 49 & 3 & 23 & 14 \\
1981 & 48 & 4 & 23 & 19 \\
1982 & 80 & 9 & 38 & 43 \\
1983 & 103 & 10 & 48 & 47 \\
1984 & 86 & 14 & 40 & 66 \\
1985 & 325 & 16 & 153 & 76 \\
1986 & 926 & 18 & 435 & 85 \\
1987 & 1,201 & 59 & 564 & 279 \\
1988 & 1,924 & 81 & 904 & 383 \\
1989 & 2,001 & 99 & 940 & 468 \\
1990 & 1,132 & $\underline{338}$ & $\underline{532}$ & $\underline{1,598}$ \\
\hline $10 T A L S$ & 7,878 & 651 & $-3,700$ & 3,078
\end{tabular}


TABLE A.4 Fuel Age Distribution in Transport, \% by age

\begin{tabular}{lrcc}
$\begin{array}{l}\text { Fuel } \\
\text { Age, } \\
\text { Years }\end{array}$ & $\begin{array}{l}\text { Case 1 } \\
\text { FCR, no } \\
\text { rerack }\end{array}$ & $\begin{array}{c}\text { Case } 2 \\
\text { No FCR } \\
\text { no rerack }\end{array}$ & $\begin{array}{c}\text { Case 3 } \\
\text { FCR, rerack } \\
\text { to 10/3 Cores }\end{array}$ \\
\hline 0 & 3.3 & & \\
1 & 37.7 & & \\
2 & 29.7 & & \\
3 & 11.0 & 3.9 & \\
4 & 3.9 & 16.9 & 2.5 \\
5 & 5.0 & 22.8 & 4.0 \\
6 & 2.3 & 19.2 & 93.4 \\
$>6$ & 7.1 & 37.1 &
\end{tabular}




\section{REFERENCES}

1. R. A. Burnett and C. W. Rolland, Transportation Logistics Modeling for the Spent Fuel Handling and Packaging Program, PNL-SA-6893, Pacific Northwest Laboratory, Richland, Washington.

2. W. B. Andrews, R. A. Burnett and R. L. Engel, Transportation Logistics for Spent Fuel Storage and Disposal, PNL-SA-7030, Pacific Northwest Laboratory, Richland, Washington.

3. W. B. Andrews et al., Pacific Northwest Laboratory (PNL) Spent Fuel Transportation and Handling Facility Models, PNL-3105, Pacific Northwest Laboratory, Richland, Washington, September 1979.

4. "World List of Reactors", Nuclear News, Publ ished by American Nuclear Society, La Grange Park, Illinois, August 1978.

5. Colman B. Woodhal1, U.S. LWR Spent Fuel Inventory and Projection, Y/OWI/SUB-77/42500, Prepared by Nuclear Assurance Corporation for the Office of Waste Isolation, June 1977. 


\section{APPENDIX B}

SHIPPING CASK SHIELDING ANALYSIS 


\section{APPENDIX B}

\section{SHIPPING CASK SHIELDING ANALYSIS}

The large variation in dose associated with the spectrum of spent fuel age in shipment necessitated a shielding analysis of the NFS and NLI 10/24 casks. The design analysis data for these casks given in their respective SARs $(1,2)$ are limited to the short cooled source terms. This study required the dose rates for all spent fuel ages in shipment.

Gamma dose rates for the cask assemblies were calculated with the computer program ISOSHLD. ${ }^{(3)}$ The gamma source strength from the spent fuel was calculated internal to ISOSHLD by the subroutine $\operatorname{RIBD},{ }^{(4,5)}$ a fission product inventory analys is (generation, transmutation and decay) which gives results virtually identical to those obtained with ORIGEN. ${ }^{(6)}$ Neutron yields from the spent fuel were calculated with ORIGEN and modified for subcritical multiplication using the criteria of Devillers and Blum. (7)

The neutron dose equivalent rates were calculated by hand methods using the cylindrical volume source equations given by Rockwe11 ${ }^{(8)}$ and removal cross sections given by Schaeffer ${ }^{(9)}$ modified for the water shield thickness of the respective casks.

The neutron and gamma dose equivalent rates calculated for these casks for spent fuel ages to 10 years are shown in Figures B. 1 and B.2. For NFS-4, the dose equivalent rates are given (Figure B.1) at the cask surface and at a distance of 10 and 50 feet from the cask centerline. Both casks are similarly designed in that, for short cooled fuel, the controlling dose is gamma radiation and for long cooled fuel ( $>31 / 2$ years) the controlling dose is neutron. The sum of the neutron and gamma dose (see Figure B.2) was used in the population exposure model (Appendix C). Gamma dose rate falls quickly with increased fuel age throughout the age range of interest. Neutron dose equivalent rate, however, falls quickly for the initial two-year period and falls slowly thereafter. 
For purposes of modeling population exposure (Appendix $\mathrm{C}$ ), it was necessary to convert the cask to equivalent point sources. $K$ factors were defined which are the dose equivalent rate at 1 meter from an equivalent point source.

These factors are unique for each population group to adjust for the distributed source geometry and were divided into 8 age increments. Eight years was used to approximate all fuel aged greater than 6 years.

For the truck cask, three $\mathrm{K}$ factor categories apply to the following population groups:

- General Public, IDI, 2, 3 (average exposure distance $50 \mathrm{ft}$ )

- Meal Stops, ID5 (average exposure distance $10 \mathrm{ft}$ )

- Occupational workers, ID6 (average exposure distance $4 \mathrm{ft}$ )

Dose equivalent rates for the driver and passenger (alternate driver in passenger seat or sleeper), ID4, are given in Table B.1. These data are based on a driver seat to cask distance of $17.5 \mathrm{ft}$.

The data of Tables B.1 and B.2 are total dose equivalent rate ( $r$ plus $n$ ). For BWR spent fuel shipment (2 elements per shipment - 40,000 MWD/Ton) the tabular values were multiplied by 0.838 .

TABLE B.1. Truck Cab Dose Equivalent Rate, PWR

\begin{tabular}{c} 
Fuel Age \\
\hline 120 days \\
1 year \\
2 \\
3 \\
4 \\
5 \\
6 \\
$>6$
\end{tabular}

$$
\begin{gathered}
\text { Dose Rate (mrem/hr) } \\
\hline 2.0(8.44)(\mathrm{a}) \\
2.0(4.53)^{(\mathrm{a})} \\
2.0(2.10)^{(\mathrm{a})} \\
1.15 \\
.75 \\
.52 \\
.39 \\
.23
\end{gathered}
$$

\footnotetext{
(a) Dose rate without the auxiliary shielding added to limit cab dose rate to $2 \mathrm{mrem} / \mathrm{hr}$.
} 
TABLE B.2. Truck Cask K Factors, PWR (mrem- $\mathrm{m}^{2} / \mathrm{hr}$ )

\begin{tabular}{|c|c|c|c|}
\hline Fuel Age & ID1, 2, 3 & ID5 & ID6 \\
\hline 120 days & 54.8 & 34.1 & 14.3 \\
\hline 1 year & 28.1 & 18.2 & 7.72 \\
\hline 2 & 13.8 & 8.98 & 3.79 \\
\hline 3 & 7.45 & 5.00 & 2.12 \\
\hline 4 & 6.10 & 3.50 & 1.53 \\
\hline 5 & 4.00 & 2.77 & 1.21 \\
\hline 6 & 3.48 & 2.42 & 1.06 \\
\hline$>6$ & 2.88 & 2.03 & .88 \\
\hline
\end{tabular}

For train cask shipments, two sets of $k$ factors (Table B.3) were used; the first set (based on an exposure distance at $50 \mathrm{ft}$ ) applies to IDI to 5 , the second set (based on exposure $10 \mathrm{ft}$ from $\Phi$ of cask) is for ID6. $K$ factors for BWR fuel loads are lower than PWR fuel loads by a factor of 0.836 .

TABLE B.3. Train Cask $K$ Factors, PWR (mrem $-\mathrm{m}^{2} / \mathrm{hr}$ )

\begin{tabular}{lcc} 
Fuel Age & $\begin{array}{r}\text { ID1 to } 5 \text { (Avg. exposure } \\
\text { distance } 50 \mathrm{ft} . \text { ) }\end{array}$ & $\begin{array}{c}\text { ID6 (Avg. exposure } \\
\text { distance 10 ft.) }\end{array}$ \\
\cline { 2 - 3 } 150 days & 110. & 57.6 \\
1 year & 69.5 & 35.5 \\
2 years & 29.4 & 17.3 \\
3 years & 17.5 & 10.4 \\
4 years & 12.3 & 7.20 \\
5 years & 9.76 & 5.58 \\
6 years & 8.53 & 4.86 \\
$>6$ years & 7.37 & 4.02
\end{tabular}

The shielding analyses are based on PWR fuel with the properties listed in Tab:e B.4. 
TABLE B.4. Spent PWR Fuel Element Description

$\begin{array}{ll}\text { Burnup } & 40,000 \mathrm{MWD} / \mathrm{MTHM} \\ \text { Fuel Content } & .461 \mathrm{MTHM} / \mathrm{element} \\ \text { Irradiation Time } & 3 \text { years } \\ \text { Average Power } & 16.8 \mathrm{MW} \\ \text { Width } & 8.426 \mathrm{in} \\ \text { Length (Active) } & 150 \mathrm{in} \\ \text { Length (Overal1) } & 176 \mathrm{in} \\ \text { Exposure Flux } & 5.41 \times 10^{13} \\ \text { Conversion Ratio } & .156\end{array}$

The truck cask has the pertinent shield materials and dimensions 1 isted in Table B.5; the corresponding rail cask data are given in Table B.6.

TABLE B.5. NFS-4 Cask Description (in.)

Outside Dimensions:

Length 214

Diameter

Cavity Dimensions:

Length 178

Diameter 13.5

Shield Configuration:

(Layers starting from inside)

SS Fuel Basket .75

SS Pressure Shell .25

Lead and Shield 6.63

SS Penetration Barrier 1.25

Borated $\mathrm{H}_{2} \mathrm{O}$ n shield

4.5

SS Outer Shell

Capacity:

1 PWR Element in Fuel Basket, wet ${ }^{(a)}$

2. BWR Element in Fuel Basket, Wet ${ }^{(a)}$

(a) Subcritical multiplication factor 2.86 based in Keff $=0.65(\operatorname{Ref} 7)$ 
TABLE B.6. NLI 10/24 Cask Description (in.)

Outside Dimensions:

Length

204.8

Diameter

88

Cavity Dimensions:

Length

179.5

Diameter

45.0

Shield Configuration:

(Layers Starting from Inside)

$\mathrm{Ag} / \mathrm{In} / \mathrm{Cd}$ Fuel Basket $\quad .24$

SS Inner Shell $\quad .75$

Lead and Shield 6

SS Penetration Barrier 2

Borated $\mathrm{H}_{2} \mathrm{O}$ Shield 9

SS Outer Shell

Fins 3

Capacity:

10 PWR Elements in Fuel Basket, dry (a)

24 BWR Elements in Fuel Basket, dry (a)

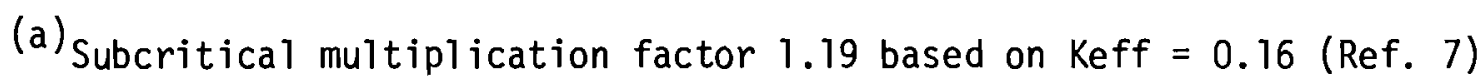

Dose rates at the cask ends were calculated using the configurations given in the SARs. ${ }^{1,2)}$ Use of a stainless steel spacer inside the truck cask in the direction of the cab was assumed (common practice). 


\section{REFERENCES}

1. Safety Analysis Report for Nuclear Fuel Services Inc. Spent Fuel Shipping Cask, Model No. NFS-4, Nuclear Fuel Services, Inc., 6000 Executive Blvd., Rockville, Maryland 20852, December 20, 1971.

2. Safety Analysis Report for NL Industries Spent Fuel Shipping Cask Model No. NLI 10/24. NL Industries, Inc., Nuclear Division, Wilmington, De1aware, 19801, 1973.

3. R. L. Engel, J. Greenborg and M. M. Hendrickson, ISOSHLD - A Computer Code for General Purpose Isotope Shielding Analysis, BNWL-236, Pacific Northwest Laboratory, Richland, Washington, June 1966, Sup. 1, March 1967, Sup. II, April 1969.

4. D. R. Marr, A Users Manual for Computer Code RIBD-II, A Fission Product Inventory Code, HEDL-TME-75-26, January 1975.

5. R. 0. Gumprecht, Mathematical Basis of Computer Code RIBD, DUN-4136, June 1968.

6. M. J. Bel1, ORIGEN - The ORNL Isotope Generation and Depletion Code, ORNL-4628, Oak Ridge National Laboratory, Oak Ridge, Tennessee. May 1973.

7. C. Devillers and P. Blum "Neutron Multiplication and Shielding Problems in Pressurized Water Reactor Spent Fuel Shipping Casks," Nuclear Technology, Volume 35, August 1977.

8. Theodore Rockwel1, Reactor Shielding Design Manual, McGraw-Hill Book Company, Inc., N.Y., 1956.

9. N. M. Schaeffer, Reactor Shielding for Nuclear Engineers, TID-25951, USAEC, Office of Information Services, 1973. 
APPENDIX C

POPULATION EXPOSURE MODEL 
APPENDIX C

POPULATION EXPOSURE MODEL

\section{1 SCOPE OF MODEL}

A mathematical model was constructed to calculate the population dose for the transport of spent nuclear fuel. The model calculates external radiation dose to the following individuals: workers loading the fuel into the shipping casks, persons irradiated during the transport (by truck or rail), and workers who unload the spent fuel at the AFRs and disposal sites. Similar methodology has been employed in other shipping studies; $(1,2)$ however, the shipping routes and specific interest in spent fuel necessitated this work.

The model represents the cask as a point source. Since the point source approximation fails near the cask, additional dose ${ }^{(a)}$ rate factors (calculated with the computer code ISOSHLD ${ }^{(3)}$ ) were used to detail the dose rates at the sides and ends of the cask. The dose rate factors are explained in Appendix B. The effect of scatter from the ground and buildings was ignored.

\section{C.2 DOSE MODEL FOR TRUCK SHIPMENTS OF SPENT NUCLEAR FUEL \\ C.2.1 Truck Shipment Description}

The dose model is based on the following truck shipment scenario. Spent fuel is remotely loaded from the reactor spent fuel storage basin into the shipping cask. The shipping cask specification for this study is the NFS-4. (4) A shipment in NFS-4 cask consists of 1 PWR element or 2 BWR elements. The cask is transported on a semi-tractor-trailer. The shipments are routed on freeways with the assumption that congested areas (i.e., rush hour traffic) are avoided when possible (see Appendix D). Two drivers work in alternating 8-hour shifts, thereby minimizing shipment time. After 4 hours driving time, a one hour stop at a truck stop for food and/or fuel is assumed. At the truck stops, the vehicle is parked in the least congested areas. At the AFR, the fuel is remotely placed in the storage pool.

(a) The term "dose" is used as an abbreviation of "dose equivalent" in this appendix. 


\section{C.2.2 Population Model (General Public)}

The United States was divided into 5 population density areas using data from the U.S. Bureau of Census. $(5,6,7,8)$ The 5 population areas and their densities (persons $/ \mathrm{m}^{2}$ ) are:

\section{Rural East}

$$
P_{1}=1.00 \times 10^{-5} \cdot \operatorname{EXP}\left(9.708 \times 10^{-3} \cdot(\text { YEAR }-1970)\right)
$$

Rural West

$$
P_{2}=2.59 \times 10^{-6} \cdot \operatorname{EXP}\left(9.690 \times 10^{-3} \cdot(\text { YEAR }-1970)\right)
$$

Standard Metropolitan Statistical Areas

$$
P_{3}=1.485 \times 10^{-4} \cdot \operatorname{EXP}\left(1.004 \times 10^{-2} \cdot(\text { YEAR }-1970)\right)
$$

Atlantic Seaboard Metropolitan Areas

$$
P_{4}=2.665 \times 10^{-4} \cdot \operatorname{EXP}\left(8.820 \times 10^{-3} \cdot(\text { YEAR }-1970)\right)
$$

Los Angeles Metropolitan Area

$$
P_{5}=1.545 \times 10^{-4} \cdot \operatorname{EXP}\left(1.879 \times 10^{-2} \cdot(\text { YEAR - 1970)) }\right.
$$

The two special metropolitan areas around New York City and Los Angeles were identified since their population densities were significantly higher than the Standard Metropolitan Statistical Areas (SMSA) as defined by the U.S. Bureau of Census. A mapped population density by counties in the SMSAs was overlayed by the paths (see Appendix D) from each reactor to their AFR destinations. The distance through each of the 5 population density areas was tabulated for each shipment route

\section{C.2.3 Exposure Groups}

The dose calculation was categorized in the following six groups

\section{C.2.3.1 ID1 - Dose to Persons Residing Along the Shipment Route}

IDI was calculated using eq. (37), which is derived in Section C.4.

$$
I D 1=\sum_{i=1}^{5} \frac{4 \cdot P_{i} \cdot L_{i} \cdot K \cdot I 2(d)}{V_{i}}
$$


where $P_{i}=$ population density in persons $/ \mathrm{m}^{2}$ in each of the 5 areas described in the population model.

$\mathrm{L}_{i}=$ length of trip in meters through each of the population areas.

$K=$ dose factor as a function of fuel age and type. See $C$ and eq. (39) in Section C.4.

$$
\begin{aligned}
\mathrm{I} 2(\mathrm{~d})= & \text { definite integral, } \int_{y=d}^{\mathrm{y}=\infty} \int_{x=0}^{\mathrm{x}=\infty} \frac{B(x, y) \mathrm{e}^{-\mu\left(x^{2}+y^{2}\right)^{1 / 2}}}{x^{2}+y^{2}} \mathrm{dx} d y \\
& \text { (See Eq. } 43, \text { Section } \mathrm{C.4}) \\
\mathrm{d}= & \text { Distance from freeway to nearest person } \\
& \text { Rural areas } \mathrm{d}=30 \text { meters; I2 }(30)=2.45 \\
& \text { Metropolitan areas } \mathrm{d}=15 \text { meters; I2(15) }=3.43 . \\
\mathrm{V}= & \text { Truck speed } \\
& \text { Rural areas } \mathrm{V}_{1,2}=88,500 \mathrm{~m} / \mathrm{hr}(55 \mathrm{mph}) \\
& \text { Metropolitan areas } \mathrm{V}_{3,4,5}=72,400 \mathrm{~m} / \mathrm{hr}(45 \mathrm{mph})
\end{aligned}
$$

Consistent with WASH-1238(9), only the people residing within $1 / 2 \mathrm{mile}$ on each side of the highway were considered exposed.

\section{C.2.3.2 ID2 - Dose to Persons Traveling in the Opposite Direction}

The dose to persons traveling in the opposite direction can be derived from eq. (40) in Section C.4. The dose to a single individual traveling at speed $v_{1}$ at a distance $y$ from the path of a source moving at $v_{2}$ :

$$
D(y)=\frac{2 K}{\left(V_{1}+V_{2}\right)} \cdot I 1
$$

where $K=$ dose factor

The integrated dose over each population zone in person-rem for persons in cars in the opposing lane of traffic is:

$$
I D 2=\frac{K \cdot L \cdot N \cdot T}{V^{2}} \cdot I 1(y)
$$


where $K=$ dose factors $\left(m r e m-m^{2} / h r\right)$ as defined for IDI

$L=$ length of the trip (meters) in each population zone

$\mathrm{N}=$ number of persons/vehicle $=1.4$

(This number ranges between 1.2 to 1.4 for all vehicles on freeways. The data was provided by the U.S. Department of

Transportation, Federal Highway Administration, Division of Highway Statistics.)

$T=$ traffic count in vehicles per hour $(a)$

$\mathrm{T}_{1}=379$ vehicles/hr in rural East

$\mathrm{T}_{2}=289$ vehicles/hr in rural West

$\mathrm{T}_{3}=1267$ vehicles/hr in metropolitan areas

$V=$ speed of vehicle

$V_{1}=55 \mathrm{mph}=88500 \mathrm{~m} / \mathrm{hr}$ in rural areas

$V_{2}=45 \mathrm{mph}=72400 \mathrm{~m} / \mathrm{hr}$ ii metropolitan areas

$I I(y)=\int_{0}^{\infty} \frac{B(x, y) \cdot e^{-\mu}\left(x^{2}+y^{2}\right)^{1 / 2} d x}{x^{2}+y^{2}}$

The average distance $(y)$ between opposing lanes of traffic in metropolitan areas is 12.2 meters (40 feet). For freeways in rural areas, $y$ is $15.2 \mathrm{~m}$ $(50 \mathrm{ft})$. The corresponding values of the integrals are:

$$
\begin{aligned}
& \mathrm{I} 1(15.2 \mathrm{~m})=0.0954 \mathrm{~m}^{-1} \\
& \mathrm{I} 2(12.2 \mathrm{~m})=0.121 \mathrm{~m}^{7}
\end{aligned}
$$

\section{C.2.3.3 ID3 - Dose to Persons Traveling in the Same Direction}

The dose rate to an adjacent vehicle traveling in the same direction separated by a constant distance(s), (see Equation 39 in Section C.4) is

$$
D R=k \cdot B(s) \cdot \frac{e^{-\mu s}}{s^{2}}
$$

For a travel distance, $L$, at constant speed, $V$, the dose is

$$
D=D R \cdot \frac{L}{V}
$$

(a) These numbers are averages of traffic counts taken by the U.S. Department of Transportation, Federal Highway Administration, Automatic Traffic Recorder Data for 1977 for a selection of routes used in this study. 
For $\mathrm{N}$ persons per vehicle and summing over all vehicles in the lane of traffic, the integrated dose is:

$$
\text { ID3 }=\frac{2 \cdot K \cdot L \cdot N}{V \cdot S^{2}} \quad \sum_{j=1}^{\infty} \frac{B(j s) e^{-\mu s j}}{j^{2}}
$$

where $K=$ dose factor $\left(r e m-m^{2} / h r\right)$ as defined for IDI.

The separation distance, $S$, is related to traffic count, $T$, by

$$
S=V / T
$$

where $V=$ speed of vehicles in meters $/ \mathrm{hr}$

$T=$ traffic count in vehicles/hr.

Only about 8 people (in the nearest vehicles) receive a significant dose. To be conservative, the same 8 people were assumed to be exposed during the 4 hours between stops.

\section{C.2.3.4 ID4 - Dose to the Truck Crew}

The two drivers are 4.6 meters (15 feet) from the end of the cask containing one PWR fuel element (.45 MTU). The integrated dose is the dose rate multiplied by shipment time; where the shipment time is the distances in the metropolitan and rural areas divided by their respective speeds. The integrated dose to the truck crew is

$$
\mathrm{ID4}=2 \cdot \mathrm{DR} \cdot((\mathrm{L} 1+\mathrm{L} 2) / 88500+(\mathrm{L} 3+\mathrm{L} 4+\mathrm{L} 5) / 72400)
$$

where $L 1$ to $L 5=$ distance through each population zone as defined for IDI. $D R=$ dose rate in cab (See Appendix $B$ ).

\section{C.2.3.5 ID5 - Dose to Bystanders at Stops}

The largest dose to bystanders occurs when the truck stops for fuel and food. The stops were modeled as follows. The vehicle is stopped for one hour resulting in exposures to the following persons. A pump attendant is located at 10 feet ( 3.05 meters) from the side of the cask for 15 minutes during fueling. His dose $D 1$ was based on the 10-ft dose factors discussed in Appendix B. 
One person is assumed to be within 13 feet of the cask during the onehour stop. This person accounts for sleepers, movement to and from other trucks and persons sitting in nearby trucks or cars. The dose to that individual is

$$
\mathrm{D} 2=\mathrm{K}(\mathrm{j}) /(3.90)^{2}=6.56 \times 10^{-2} \cdot \mathrm{K}(\mathrm{J}) \text { mrem }
$$

where the dose factors, $K$, are defined for IDI as a function of fuel age and type.

The truck is parked 250 feet (76.2 meters) from the cafe which contains 150 people. The dose to the occupants of the cafe is

$$
D 3=150 \cdot \mathrm{K}(\mathrm{J}) /(76.2)^{2}=2.58 \times 10^{-2} \cdot \mathrm{K}(\mathrm{J}) \mathrm{rem}
$$

Thus the total dose per stop is given by

$$
D=D 1(\mathrm{~J})+\left[6.56 \times 10^{-2} \cdot \mathrm{K}(\mathrm{J})\right]+\left[2.58 \times 10^{-2} \cdot \mathrm{K}(\mathrm{J})\right] \mathrm{rem}(11)
$$

Since there are no fractional stops, the algorithm for the number of stops is

$$
\text { NSTOP }=\text { INTEGER } \frac{((L 1+L 2) / 88500+(L 3+L 4+L 5) / 72400)}{4}
$$

where the L's are the lengths of the trip in the 5 population zones. The integrated dose to bystanders is then given by:

$$
I D 5=\left(D 1(J)+9.14 \times 10^{-2} \cdot K(J)\right) \cdot(\text { NSTOP }) \text { person-rem }
$$

The total number of people exposed is

$$
\begin{aligned}
\text { TRAVELERS }= & {[.00599 \cdot \mathrm{L} 1]+[.00457 \cdot \mathrm{L} 2]+[.0245 \cdot} \\
& (\mathrm{L3}+\mathrm{L} 4+\mathrm{L} 5)]+[\text { NSTOP } \cdot(160 .)]
\end{aligned}
$$

\section{C.2.3.6 ID6 - Dose to Workers Loading and Unloading the Cask}

The dose from unloading ${ }^{(10)}$ a truck cask containing 150-day-0ld fuel is 0.087 person-rem. About $20 \%$ of this dose is due to background at the loading facility, the remaining $80 \%$ is due to direct radiation from the cask. Differences in the age of the fuel are accounted for by the ratios of the dose factors given in Table B.1. 
Since the cask surface becomes contaminated in the storage pool, loading operations include an additional dose during the loaded cask decontamination. A survey of 3 decon groups at the Hanford site estimated the cask decontamination time to be 1 to 2 hours:for two operators. A health physics technician would also spend 20 to 30 minutes to survey the cask. The decon operations involve two chemical decon treatments applied with a 5-ft applicator; thus the operators are $6 \mathrm{ft}$ from the cask. The health physics technician would be at a distance of $2 \mathrm{ft}$ while taking contamination smears. ISOSHLD ${ }^{(3)}$ calculated this DECON dose to be .029 man-rem. The total occupational dose (loading and unloading) is

$$
\mathrm{ID6}=0.034+\left[(0.140+\mathrm{DECON}) \cdot \frac{\mathrm{K}(\mathrm{J})}{\mathrm{K}(1)}\right] \text { (person-rem) }
$$

There are 12 workers involved in the loading and unloading of each shipment (two crews of six men).

\section{C.3 DOSE MODEL FOR RAIL SHIPMENTS OF SPENT NUCLEAR FUEL}

\section{C.3.1 Rail Shipment Description}

This model is based on the following rail shipment concept. Spent fuel is remotely loaded from the reactor storage basin into the shipping cask. The rail cask specification selected for this study was that of the NLI 10/24. (11) The cask holds 10 PWR elements (4.5 MTU) or 24 BWR elements (4.7 MTU). The cask is loaded onto a special rail car with auxiliary cooling equipment, personnel barriers, etc.

As ordinary freight, the cask is taken to a switch yard, where it will spent a day or two waiting for a train to go in the correct direction. A typical rail shipment will move from one major switch yard to another in the general direction of the destination. If the rail cask is sent by special train, the number of long stops enroute is minimized.

At the storage site, the fuel elements are unloaded, and the shipping cask is decontaminated, if necessary, and returned. 


\section{C.3.2 Calculational Model for Rail Shipments}

The dose to the general population and workers in proximity of the spent fuel shipment has been broken down into six groups as follows.

\section{C.3.2.1 IDI - Dose to the Population Residing Along the Path of the Shipment}

The dose to the persons along the sides of the track is (See Eq. 43, Section (.4):

$$
\text { IDI }=\frac{4 \cdot P \cdot L \cdot K \cdot I 2(d)}{V}=P \cdot L \cdot K \cdot \alpha
$$

where $P=$ population density (as described in Section C.2.2)

$L=$ length of the trip through each population area

$K=$ dose factor as a function of fuel age (See Appendix B).

$\mathrm{I} 2(\mathrm{~d})=$ same as for truck cask (See Section C.2.2)

$V=$ speed of train in meters/hr

$V_{1}=50 \mathrm{mph}$ rural areas

$v_{2}=25 \mathrm{mph}$ metropolitan areas

$\alpha=\frac{4 \cdot I 2(d)}{V}$

$\alpha_{1}=1.22 \times 10^{-4} \mathrm{~m}^{-1} \mathrm{hr}$ in rural

$\alpha_{2}=2.96 \times 10^{-4} \mathrm{~m}^{-1} \mathrm{hr}$ in metropolitan

\section{C.3.2.2 ID2 - Dose to Persons in Adjacent Trains Traveling in the Opposite Direction}

The dose to persons traveling in the opposite direction is derived using eq. (40) in Section C.4. The dose to $M$ people for each segment of the trip is

$$
\text { ID2 }=\frac{2 \cdot K \cdot M \cdot I I(y)}{V_{a}+V_{b}}
$$

where $I I(y)=0.595 \mathrm{~m}^{-1}$. (See Eq. 4) for tracks that are 8.5 feet $(2.6$ meters) apart.

In rural areas the passenger train has priority and the freight train is stopped; therefore, $v_{a}+v_{b}=50 \mathrm{mph}=80400 \mathrm{~m} / \mathrm{hr}$. 
In metropolitan areas assume both trains are traveling $25 \mathrm{mph}$, thus $\mathrm{V}_{\mathrm{a}}+\mathrm{V}_{\mathrm{b}}=50 \mathrm{mph}=80400 \mathrm{~m} / \mathrm{hr}$.

If the trains travel faster, the results are conservative.

$M=$ Number of persons in each train traveling in the opposite direction.

NUREG-0170, Vol $1^{(1)}$ assumes the rail cask meets five passenger trains per day in metropolitan areas and one passenger train per day in rural areas. Data from AAR $(12)$ incidate that AMTRAC and auto trains carry 96.7 persons/ train on the average, and commuter trains carry 231 passengers/ train. AMTRAC travels $48.3 \mathrm{mph}$ and commuter trains travel at $33.1 \mathrm{mph}$ (including time at stops).

Time in rural areas TIMER $=(\mathrm{L} 1+\mathrm{L} 2) / 77750$. (hours)

Time in metro areas TIMEM $=(\mathrm{L} 3+\mathrm{L} 4+\mathrm{L} 5) / 53260$. (hours) $M=[96.7 \cdot$ INTEGER (TIMER/24.) $]+[5 \cdot 231$ INTEGER (TIMEM/24.)]

\section{C.3.2.3 ID3 - Dose to Persons Traveling in the Same Direction}

Dose to a person along the path of the train where the source vehicle moves with a speed $V_{a}$ and the passenger moves at a speed $V_{b}$ is

$$
\text { ID3 }=\frac{2 \cdot K \cdot M \cdot I I(y)}{\left|V_{a}-V_{b}\right|}
$$

All variables are as previously defined. In rural areas the freight train is sided and waits for the passenger train to pass, therefore,

$$
\left|v_{a}-v_{b}\right|=50 \mathrm{mph}
$$

In metropolitan areas the passenger train overtakes the freight train by $10 \mathrm{mph}$

$$
\left|V_{a}-V_{b}\right|=10 \mathrm{mph}
$$




\section{C.3.2.4 ID4 - Dose to Train Crew}

The crew consists of two persons in the locomotive and two in the caboose. The loaded rail cask car weighs 320,000 pounds, so it is placed in the front third of the train with at least one car between locomotive and cask.

This assumption is equivalent to representing the cask as a line source $1 / 3$ the length of the train. The dose rate from a segment $d r$ of the line source is:

$$
d(D R)=k \cdot \frac{3}{L T} \cdot \frac{B(r) e^{-\mu r}}{r^{2}} \cdot d r
$$

The dose at a point from the entire line source becomes

$$
D R=\frac{3 K}{L T} \int_{\min }^{\max } \frac{B(r) e^{-\mu r}}{r^{2}} d r
$$

where $K$ is the dose factor of IDI

$\mathrm{LT}$ is the length of the train. The average freight train is 67.2 cars long, (13) and the average car is $60 \mathrm{ft}$ long. Hence LT is 1229 meters.

The integral,

$$
\text { I3 }=\int_{\min }^{\max } \frac{B(r) \cdot e^{-\mu r}}{r^{2}} d r
$$

is evaluated numerically. The minimum distance to the locomotive is 90 feet (27.43 meters); the maximum distance is LT/3 or 409.7 meters. The minimum distance to the caboose is $2 / 3$ LT ( 819.3 meters); the maximum distance is LT=1229 meters.

For the locomotive, I3 $=.04 \mathrm{~m}^{-2}$

For the caboose, $\mathrm{I} 3=8.7 \times 10^{-6} \mathrm{~m}^{-2}$

A train crew travels $250 \mathrm{mi} /$ day $(402,250$ meters), then waits 30 minutes for the next crew to take over. The time waiting is the number of stops times the time per stop: 


$$
\text { TWAIT }=0.5 \cdot(L 1+L 2+L 3+L 4+L 5) / 402250
$$

The crew time on the moving train is

$$
\text { TRUN }=(L 1+L 2) / V_{\text {rural }}+(L 3+L 4+L 5) / V_{\text {metro }}
$$

For a train speed of $50 \mathrm{mph}(80,450 \mathrm{~m} / \mathrm{hr})$ in rural areas and $25 \mathrm{mph}$ $(40225 \mathrm{~m} / \mathrm{hr})$ in metropolitan areas:

$$
\text { TRUN }=(L 1+L 2) / 80450+(L 3+L 4+L 5) / 40225
$$

The total time is:

$$
\text { TTIME = TWAIT + TRUN }
$$

The dose to the 4-man train crew, including crew change time, is:

$$
\text { ID4 }=(\operatorname{TTIME} \cdot 6 \cdot(\mathrm{K} / \mathrm{LT})) \cdot(\text { I3 (locomotive })+\mathrm{I} 3 \text { (caboose) })
$$

The model considers only one rail cask per train.

\section{C.3.2.5 ID5 - Integrated Dose to Yard Workers}

Freight trains frequently stop at rail sidings to let other trains pass and/or pick up more cars. There is little information available for an average rail yard. For consistency in calculational models, we are using the data from NUREG-0170, Vol. 1. (1) The worker density is estimated to be 25 people per $\mathrm{km}^{2}$, corresponding to 20 employees in a rail yard $1.6 \mathrm{~km}$ long by $0.5 \mathrm{~km}$ wide, or correspondingly, an annular region with a maximum diameter of $252 \mathrm{~m}$. The incremental dose rate in an annulus with a width $d r$ at a distance $r$ from a point source is:

$$
d(D R)=2 \pi \cdot r \cdot k \frac{B(r) e^{-\mu r}}{r^{2}} d r
$$

Integrating, multiplying by the population density (PD) and by the exposure time (TIME) gives the total dose:

$$
\text { IDYARD }=\text { TIME } \cdot P D \cdot(2 \pi \cdot K \cdot I 4)
$$


where $K$ is the dose factor as a function of fuel age

$$
I 4=\int_{\min }^{\max } \frac{B(r) \cdot e^{-\mu r}}{r} d r
$$

The distance of closest approach is about $71 / 2$ feet (2.3 meters) from the center of the cask. The maximum distance is $252 \mathrm{~m}$. The value of I 4 was numerically computed to be 4.32 .

Limited information suggests that for the long distances between reactors and the AFRs, the time spent on sidings and in yards is about the same as the time spent in transit; see TRUN for ID4.

In addition to the above dose, the train is inspected every time it stops. The dose to a person walking along the side of the train at a distance of $71 / 2$ feet $(2.3$ meters) at a speed $V$ of $2 \mathrm{mph}$ (3220 meters/hour) can be found from equation (40) in Section C.4:

$$
W D=\frac{2 K}{V} \cdot I I(y)
$$

The train stops every 250 miles $(402,250$ meters). The number of stops per trip is:

$$
N S=(L T+L 2+L 3+L 4+L 5) / 402250 .
$$

The train inspecting dose is the product of WD * NS or

$$
I D S T O P=\frac{2 K}{V} \cdot I I(y) \cdot(L I+L 2+L 3+L 4+L 5) / 402250 .
$$

where $K$ is the dose factor (see IDI)

Il $(y)$ is the numerically evaluated integral, which has a value of $0.676 \mathrm{~m}^{-1}$ at a distance of $y=2.3$ meters

LI to $L 5$ are the distances through each population zone.

The total dose to railroad workers (excluding the train crew) is thus:

$$
\text { ID5 = IDYARD + IDSTOP }
$$




\section{C.3.2.6 ID6 - Integrated Dose to Crews Handling Casks}

Wide variations are possible in the occupational exposure to workers loading and unloading rail casks. The utilities usually provide their own crew for loading casks. These crews have greatly different degrees of experience, and inexperienced crews who take more time receive greater doses. The fuel storage basins have varying amounts of radioisotopes in the water (usually ${ }^{134} \mathrm{Cs},{ }^{137} \mathrm{Cs},{ }^{60} \mathrm{Co},{ }^{63} \mathrm{Ni}$ and ${ }^{3} \mathrm{H}$ ) and the casks may take more time to decontaminate. The NLI 10/24 rail cask is extensively finned, and the fins are difficult to decontaminate. For this study, we have assumed that a plastic (or metal) contamination barrier is placed around the cask before it is placed in the bas in to reduce the amount of decontamination necessary.

Anderson ${ }^{(10)}$ gives a detailed study of the procedures, times, manpower requirements and radiation doses involved in unloading the NLI 10/24 rail cask at the Barnwell facility. The unloading dose to a 6 man crew is 244 mrem per cask of 10 PWR elements or 24 BWR elements (150 day old fuel). of this $244 \mathrm{mrem}$, room backgrounds give $50 \mathrm{mrem}$ and the fuel in the cask gives $194 \mathrm{mrem}$ (which varies with fuel age and type). Thus the rail cask unloading dose is:

$$
\text { unloading dose }=0.050+\left[0.194 \cdot \frac{\mathrm{KR}(\mathrm{J})}{\mathrm{KR}(\mathrm{I})}\right] \text { person-rem }
$$

where KR are the dose factors given for IDI.

The loading doses are identical except for the following. The cask is empty when received, so the crew does not receive $3.5 \mathrm{mrem}$ during the washdown and inspection operation. The cask would be decontaminated by 2 operators in 2 hours with 1 health technician working 30 minutes (see discussion in Section B.2.2.6). The estimated dose during the decon operations is 21 mrem for the 150-day-old fuel.

The loading operation dose was divided into 3 groups: (1) room background, (2) direct exposure to the cask, and (3) decontamination. This is:

$$
\text { loading dose }=0.050+\left[(0.194-.0035) \cdot \frac{\mathrm{KR}(\mathrm{J})}{\mathrm{KR}(1)}\right]+\left[\operatorname{DECON} \cdot \frac{\mathrm{KR}(\mathrm{J})}{\mathrm{KR}(1)}\right]
$$


The sum of the loading and unloading doses is

$$
I D 6=0.101+\left[\frac{K R(J)}{K R(1)} \cdot(0.384+D E C O N)\right] \text { (person-rem) }
$$

where DECON is 0.021 person-rem for 150 day old fuel.

\section{C.4 DERIVATION OF EQUATIONS USED IN THE DOSE MODEL}

The uncollided flux from a point source is given by the equation:

$$
\phi=\frac{1}{4 \pi} \frac{S}{r^{2}}
$$

where $s=$ source strength (photons $/ \mathrm{sec}$ )

$r=$ distance from source to dose point (meters)

The dose rate from a point source assuming only attenuation and build-up in air and ignoring scatter from the ground is:

$$
D R=\left(\frac{1}{4 \pi} \cdot \frac{S}{r^{2}} \cdot B(r) e^{-\mu r}\right)\left(\frac{h}{\phi}\right)
$$

where $(h / \phi)$ is the flux to dose rate conversion factor (units of rem/hr per photon $/ \mathrm{sec}-\mathrm{cm}^{2}$ ).

Combining terms:

$$
D R=K \cdot B(r) \cdot \frac{e^{-\mu r}}{r^{2}}
$$

where $K=$ dose rate factor for a unit source strength

$=1 / 4 \pi S(h / \phi)$

$B(r)=$ dose build-up factor for an isotopic source

$\mu=1$ inear attenuation coefficient $\left(\mathrm{m}^{-1}\right)$

Equation (39) is used to derive the remaining relationships. 


\section{C.4.1 Dose From A Moving Source}

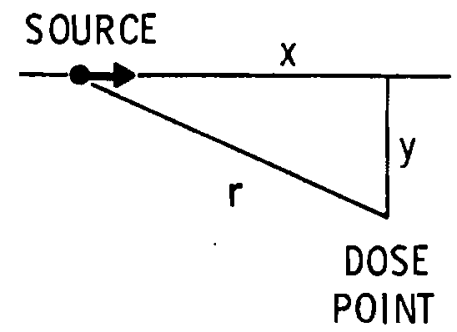

$$
\begin{aligned}
& D R=\frac{d D}{d t} \\
& d D=(D R) d t
\end{aligned}
$$

The speed of the source is defined as:

$$
v=d x / d t \text { or } d t=d x / v
$$

where $v$ is a constant speed.

The incremental dose, $d D$, is given by

$$
d D=(D R): \frac{d x}{v}
$$

Substituting the dose rate from a point source from Equation (3a) gives:

$$
d D=k \cdot B(r) \cdot \frac{e^{-\mu r}}{r^{2}} \cdot \frac{d x}{v}
$$

At a constant speed, $v$, the total dose is given by

$$
D=\frac{K}{V} \int_{x=-\infty}^{x=+\infty} \frac{e^{-\mu r}}{r^{2}} \cdot B(r) \cdot d x
$$

Since this integrand is symmetric about the origin, the limits of integration can be changed and the distance $r$ can be related to the distances $x+y$ by the Pythagorean theorem $\left(r^{2}=x^{2}+y^{2}\right)$ to give: 


$$
D(y)=\frac{2 K}{V} \int_{0}^{\infty} \frac{B(x, y) \cdot e^{-\mu\left(x^{2}+y^{2}\right)^{1 / 2}}}{x^{2}+y^{2}} d x
$$

This equation can be evaluated numerically to give the dose to a single individual from a source moving at a constant speed, $v$.

C.4.2 Integrated Dose to a Uniformly Distributed Population Along the Path of a Shipment

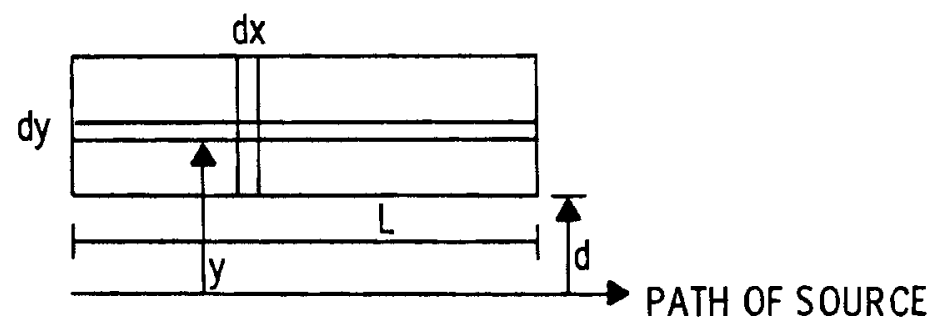

Equation (40) pertains to a single point at a distance, $y$, from the path of the source. For a uniform population density, $P$, in a strip of area Ldy, the dose, dI', to individuals in this strip is:

$$
d I^{\prime}=D(y) \cdot P \cdot L d y
$$

Integrating this from $y=\min$ to $y=\max$ and including the population on both sides of the source path gives:

$$
I=2 \cdot P \cdot L \int_{y=d}^{y=\max } D(y) d y
$$

or

$$
I=\frac{4 \cdot P \cdot L \cdot K}{V} \int_{y=d}^{y=\max } \int_{x=0}^{x=\infty} \frac{B(r) \cdot e^{-\mu\left(x^{2}+y^{2}\right)^{1 / 2}}}{x^{2}+y^{2}} d x d y
$$

The equation was integrated numerically defining the value of the integral as I2(d). Equation (42) can be rewritten as

$$
I=\frac{4 \cdot P \cdot L \cdot K \cdot I 2(d)}{V}
$$




\section{REFERENCES}

1. Final Environmental Statement on the Transportation of Radioactive Material by Air and Other Modes, NUREG-0170, Vol 1, December 1977, U.S. Nuclear Regulatory Commission, Washington, D.C., Docket \#, PR-71, 73 (40 RD)

2. H. F. MacDonald and J. H. Mairs, Individual and Collective Doses Associated with the Transport of Irradiated Magnox Fuel with the UK. RD/B/N4440, Central Electricity Generating Board, 19 Warwick Lane, London ECAP 4EB, England, December 1978.

3. R. L. Enge1, J. Greenborg, M. M. Hendrickson, ISOSHLD - A Computer Code for General Purpose Isotope Shielding Analysis, Pacific Northwest Laboratory, Richland, Washington, 1966.

4. USNRC. Certificate of Compliance No 6698 Issued to Nuclear Fuel Service, Inc., P.0. Box 124, West Valley, New York, Revision No. 5. Docket No. 71-6698.

5. U.S. Bureau of Census, Current Population Reports, Population Estimates Series P-25, No. 375. October 3, 1967, "Revised Projections of the PopuTation of States 1970 to 1985." U.S. Government Printing Office, Washington, D.C.

6. U.S. Bureau of Census, Current Population Reports, Special Studies Series P-23, No. 49. May 1974, "Population of the United States 19501990." U.S. Government Printing Office, Washington, D.C.

7. U.S. Bureau of Census, Current Population Reports, Series P-25, No. 739. "Estimates of the Population of Counties and Metropolitan Areas: JuTy 1, 1975 and 1976." U.S. Government Printing Office, Washington, D.C.

8. U.S. Bureau of Census, Statistical Abstract of the United States: 1977. (98th ed), U.S. Government Printing Office, Washington, D.C., 1977.

9. Environmental Survey of Transportation of Radioactive Materials to and from Nuclear Power Plants. WASH-1238, U.S. Atomic Energy Commission, Washington D.C., December 1972.

10. R. T. Anderson, et al., "Occupationa1 Assessment of the NLI 10/24 Spent Fuel Rail Cask," AGNS-1040-1.1-29, Allied General Nuclear Services, Barnwe11, South Carolina (1978).

11. USNRC Certificate of Compliance, No. 9023, issued to NL Industries, Nuclear Division, West Street, Wilmington, Delaware, 19801, Revision No. 0, Docket No. 71-9023. 
12. Statistics of Railroads of Class 1 in the United States: Years 1967 to 1977, Association of American Railroads, Economics and Finance Department, Washington, D.C., September 1978.

13. Yearbook of Railroad Facts (1978 edition). Association of American Railroads, Economics and Finance Department, Washington, D.C., 1978. 
APPENDIX D

SHIPMENT ROUTE MODEL 
APPENDIX D

SHIPMENT ROUTE MODEL

A truck and rail shipment route was developed for each reactor group to each away-from-reactor storage site (AFR). The truck route selections were based on interviews with the major transporters of radioactive materials. The mileages between reactor groups and AFRs were determined by the most direct route via the interstate highway system. Whenever possible, major metropolitan areas were bypassed as is normally practiced. The shipment route model contains 81 reactor groups within the contiguous United States, the three AFRs (Midwest, SE and NW) and one disposal site (SW). Several representative truck shipment routes (mileage by population density zones) are presented in Table D. 1 .

For rail shipment of spent fuel, the cask was assumed to be handled as commercial freight. As such, the cask would be transported to the nearest switchyard and coupled with a train that would be going in the proper direction. Movement of rail cars is from switchyard to switchyard and, therefore, movement is not always by the most direct route. For this study, all rail shipments were assumed to be made on the major rail lines and their interconnecting systems. The most efficient (which is not always the most direct) routes were determined with the aid of a rail dispatcher familiar with the shipment of radioactive materials. Table D.2 presents some typical rail shipment routes (mileage by population density zone).

Since some reactor groups would utilize both truck and rail shipment, Table D. 3 compares the different shipment mode mileages from a few selected reactor groups to AFRs. There is little difference in the total miles shipped; however, there is a slight change in the mileage distribution in the metropolitan areas. 
TABLE D.1 Truck Shipment Mileages

\begin{tabular}{|c|c|c|c|c|c|}
\hline $\begin{array}{l}\text { Reactor } \\
\text { Group No. }\end{array}$ & AFR & $\begin{array}{r}\text { Rural } \\
\text { West } \\
\end{array}$ & $\begin{array}{r}\text { Rural } \\
\text { East } \\
\end{array}$ & $\begin{array}{l}\text { Metropolitan } \\
\text { Areas }\end{array}$ & $\begin{array}{c}\text { Special } \\
\text { Areas }\end{array}$ \\
\hline $\begin{array}{l}52 \\
\text { (Ohio) }\end{array}$ & $\begin{array}{l}\text { Midwest } \\
\text { Northwest } \\
\text { Southeast } \\
\text { Southwest }\end{array}$ & $\begin{array}{r}0 \\
1259 \\
0 \\
241\end{array}$ & $\begin{array}{l}173 \\
444 \\
444 \\
963\end{array}$ & $\begin{array}{l}115 \\
343 \\
167 \\
481\end{array}$ & \\
\hline $\begin{array}{l}49 \\
\text { (Maryland) }\end{array}$ & $\begin{array}{l}\text { Midwest } \\
\text { Southeast } \\
\text { Southwest }\end{array}$ & $\begin{array}{r}0 \\
0 \\
241\end{array}$ & $\begin{array}{r}346 \\
426 \\
1194\end{array}$ & $\begin{array}{l}389 \\
139 \\
444\end{array}$ & 122 \\
\hline
\end{tabular}

TABLE D.2 Rail Shipment Mileages

$\begin{array}{llcccc}13 & & & & \\ \text { (Louisiana) } & \text { Southwest } & 310 & 285 & 278 & \\ & \text { Northwest } & 1402 & 601 & 211 & \\ & \text { Midwest } & -- & 634 & 226 & \\ & \text { Southeast } & -- & 550 & 165 & \\ 24 & & & & & 180 \\ \text { (New Jersey) } & \text { Southwest } & 561 & 604 & 654 & 180 \\ & \text { Northwest } & 1091 & 712 & 662 & 180 \\ & \text { Midwest } & & 297 & 414 & 226\end{array}$

TABLE D. 3 Comparison of Rail/Truck Mileages

$\begin{array}{llrrrr}31 & \text { (Rail) S.E. } & 0 & 371 & 79 & \\ \text { (Florida) } & \text { (Truck) S.E. } & 0 & 426 & 74 & \\ 34 & \text { (Rail) N.W. } & 964 & 250 & 164 & \\ \text { (Minnesota) } & \text { (Truck) N.W. } & 1111 & 222 & 157 & \\ 64 & \text { (Rail) S.W. } & 214 & 721 & 350 & \\ \text { (Indiana) } & \text { (Truck) S.W. } & 241 & 676 & 352 & 171 \\ \text { 46 } & & & & & \\ \text { (California) } & \text { (Truck) N.W. } & 714 & 0 & 215 & 130\end{array}$




\section{APPENDIX E}

INTEGRATED DOSE MODEL FOR SPENT NUCLEAR FUEL SHIPMENTS 


\section{APPENDIX E}

\section{INTEGRATED DOSE MODEL FOR SPENT NUCLEAR FUEL SHIPMENTS}

The Variable Site Model (Appendix A) produces a file containing the amount of spent fuel shipped each year by truck and rail from each reactor group to the AFRs. The amount of spent fuel shipped is measured by the number of metric tons of heavy metal (MTHM) contained in the fuel. Another file created by the Variable Site Model contains a table with the percentage of the shipments by source and year which fall in each fuel age grouping. The mean fuel ages for the eight age groupings are 120-day, 1-year, 2-year, 3-year, 4-year, 5-year, 6-year, and greater than 6-year old fuel (mean of 8 years). These files are combined with a set of dose rate factors for the casks and a file of truck and train lengths through each of five designated population areas to calculate the dosage to the population as a result of the shipments of spent fuel.

Based on the amount shipped from each reactor site, the program first calculates the number of individual shipments (cask loads). The calculation is based on the assumption that there are .47 MTHM per PWR element and .197 MTHM per BWR element. A truck cask will hold two BWR elements or 1 PWR element. A rail cask holds 24 BWR elements or 10 PWR elements. The model assumes a cask may contain a mixture of different aged fuel when necessary. If there is a mixture, the calculations are based on the age of the youngest fuel in the shipment.

The formula for calculating dose for shipments is:

No. Reactor Groups Destinations

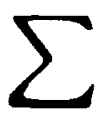

$i=1$

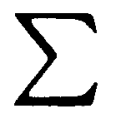

$j=1$

No. Fuel Age Groupings

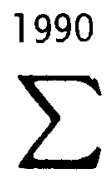

$k=1980$

(year)

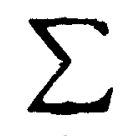

$\ell=1$

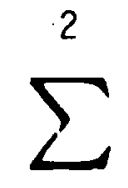

$m=1$
(No. of Shipments)

$$
i, j, k, \ell, m
$$

$$
\left(I D 1_{m}+I D 2_{m}+I D 3_{m}+I D 4_{m}+I D 5_{m}+I D 6_{m}\right)
$$


where

$i=$ index for the reactor group shipping fuel

$j=$ index for shipment distance from reactor group to AFR or repository

$k=$ index for year of shipment (from 1980 to 1990)

$\ell=$ index for fuel age group (explained in Section 3.3 Fuel Age)

$m=$ index for truck shipment or rail shipment

IDI = dose per shipment to persons residing along shipment route (for details see $p$. C-3 for truck shipments or $p$. C-9 for rail shipments)

ID2 = dose per shipment to persons trucking in the opposite direction to shipment (see p. C-4 for truck shipments or p. C-9 for rail shipments)

ID3 = dose per shipment to persons traveling in the same direction as the shipment (see p. C-5 for truck shipments or $p . C-10$ for rail shipments)

ID4 $=$ dose per shipment to crew (see p. C-6 for dose to truck crew or p. C-11 for dose to train crew)

ID5 $=$ dose per shipment to bystanders (see p. C-6 for dose to bystanders at truck stops and $p$. C-11 for dose to workers at train switch yards)

ID6 = dose per shipment to cask handling crew at loading and unloading of fuel (see $p$. C-7 for truck shipments or $p . C-14$ for rail shipments) 


\section{APPENDIX $\mathrm{F}$}

CASK CAPACITY VS FUEL AGE AND DOSE RATE SPECIFICATION 


\section{APPENDIX $F$}

\section{CASK CAPACITY VS FUEL AGE AND DOSE RATE SPECIFICATION}

Tables F. 1 through F. 4 give a matrix of truck and rail shipping cask weights for various spent fuel ages and cask capacities. Each entry is a shipping cask design which would have the specified dose rate $(10 \mathrm{mrem} / \mathrm{hr}$ at $6 \mathrm{ft}$., Tables F. 1 and F.2 and $1 \mathrm{mrem} / \mathrm{hr}$ at $6 \mathrm{ft}$., Tables F.3 and F.4) when loaded with spent fuel of the specified age. These data were calculated by the Chemical Technology Division of Oak Ridge National Laboratory with the conceptual design code, PACRAT.

The trends given in these tables are valid; however, the cask weights as given would be high by 5 to $20 \%$ (a) The shielding materials and configurations assumed in these tables is that of the NFS-4 and NLI 10/24.

(a) The NFS-4 truck cask weighs 25 tons (unloaded); its dose rate loaded with short cooled fuel is about $3.8 \mathrm{mrem} / \mathrm{hr}$ at $6 \mathrm{ft}$. (See Figure 3.3.1). 
TABLE F.1 Truck Cask Capacity and Weight Vs. Age, $10 \mathrm{mrem} / \mathrm{hr}--$ $6 \mathrm{ft}$ From Vehicle Surface

\begin{tabular}{lcccc} 
& \multicolumn{5}{c}{ Number of Assemblies (PWR/BWR) } \\
\cline { 2 - 5 } $\begin{array}{l}\text { Spent Fuel Age } \\
120 \text { days }\end{array}$ & $\frac{1 / 2^{(a)}}{30^{(b)}}$ & $\frac{1 / 3}{3 / 7}$ & $\underline{2 / 5}$ & $\underline{3}$ \\
1 year & 28 & 38 & 51 & 56 \\
2 years & 25 & 34 & 47 & 52 \\
5 years & 21 & 29 & 39 & 43 \\
10 years & 16 & 24 & 32 & 36 \\
25 years & 13 & 18 & 28 & 30 \\
$\begin{array}{l}\text { Inside Cavity } \\
\text { Diameter(in.) }\end{array}$ & 13.5 & 20 & 27.5 & 30
\end{tabular}

(a) Based on NFS-4 design philosophy: Pb gamma shield, borated water neutron shield and dry cavity.

(b) Cask weight in short tons. 
TABLE F.2 Rail Casks Capacity and Weight Vs. Age, $10 \mathrm{Mrem} / \mathrm{hr--}$ $6 \mathrm{ft}$ From Personnel Barrier

\begin{tabular}{|c|c|c|c|c|}
\hline \multirow[b]{2}{*}{ Spent Fuel Age } & \multicolumn{4}{|c|}{ Number of Assemblies (PWR/BWR) } \\
\hline & $10 / 24^{(a)}$ & $12 / 34$ & $15 / 41$ & $21 / 48$ \\
\hline 150 days & 98 & & & \\
\hline 1 year & $94^{(b)}$ & ${ }_{93}(c)$ & $105^{(c)}$ & $115^{(c)}$ \\
\hline 2 years & 88 & $87^{(c)}$ & $98^{(c)}$ & $108^{(c)}$ \\
\hline 5 years & 76 & 74 & 85 & 93 \\
\hline 10 years & 65 & 63 & 72 & 80 \\
\hline 25 years & 55 & 54 & 62 & 68 \\
\hline $\begin{array}{l}\text { Inside Cavity } \\
\text { Diameter(in) }\end{array}$ & 45 & 45 & 50 & 55 \\
\hline
\end{tabular}

(a) Based on NLI 10/24 design philosophy: Pb gamma shield, borated water neutron shield and dry cavity.

(b) Cask weight in short tons.

(c) Needs fins 
TABLE F.3 Truck Cask Capacity and Weight Vs. Age, 1 Mrem/hr-$6 \mathrm{ft}$ From Vehicle Surface

\begin{tabular}{|c|c|c|c|c|}
\hline \multirow[b]{2}{*}{ Spent Fuel Age } & \multicolumn{4}{|c|}{ Number of Assemblies (PWR/BWR) } \\
\hline & $1 / 2^{(a)}$ & $1 / 3$ & $2 / 5$ & $3 / 7$ \\
\hline 120 days & 40 & & & \\
\hline 1 year & 38 & 50 & 66 & 72 \\
\hline 2 years & 35 & 46 & 61 & 67 \\
\hline 5 years & 28 & 38 & 51 & 56 \\
\hline 10 years & 23 & 31 & 42 & 47 \\
\hline 25 years & 18 & 25 & 35 & 39 \\
\hline $\begin{array}{l}\text { nside Cavity } \\
\text { Diameter (in) }\end{array}$ & 13.5 & 20 & 27.5 & 30 \\
\hline
\end{tabular}

(a) Based on NFS-4 design philosophy: Pb gamma shield, borated water neutron shield and dry cavity. 
TABLE F.4 Rail Cask Capacity and Weight Vs. Age, $1 \mathrm{Mrem} / \mathrm{hr}$ \& $6 \mathrm{ft}$ From Vehicle Surface

\section{Spent Fuel Age}

150 days

1 year

2 years

5 years

10 years

25 years

Inside Cavity

Diameter (in)

\begin{tabular}{lcll}
\multicolumn{4}{c}{ Number of Assemblies (PWR/BWR) } \\
$\underline{10 / 24}$ (a) & $\underline{12 / 34} \quad \underline{15 / 41} \quad \underline{21 / 48}$
\end{tabular}

$119^{(b)}$

116

$114^{(c)}$

$127^{(c)}$

$138^{(c)}$

109

${ }_{107}(\mathrm{c})$

120 (c)

$131^{(c)}$

94

92

104

114

80

79

89

98

68

67

76

83

45

45

50

55

\footnotetext{
(a) Based on NLI 10/24 design philosophy: Pb gamma shield, borated water neutron shield and dry cavity.

(b) Cask weight in short tons for casks with dose rates of $1 \mathrm{mrem} / \mathrm{hr}$ at six feet from its surface.

(c) Needs fins.
} 

APPENDIX G

TRANSPORTATION ACCIDENT DATA 
APPENDIX G

\section{TRANSPORTATION ACCIDENT DATA}

NUCLEAR

Table G.1 lists the population exposures that would result from postulated spent fuel shipping accidents. These data are based on risk assessments of transporting spent fuel by truck and rail that have been performed by PNL for DOE's Environmental Control Division. The truck risk assessment has been published ${ }^{(1)}$; the rail risk assessment is in draft form with publication expected about December 1980.

\section{NON-NUCLEAR}

The accident frequency for heavy truck transport is one accident in every 400,000 miles $(2,3)$, i.e., a rate of $1.6 \times 10^{-6}$ accidents per $\mathrm{km}$. The traffic fatalities from heavy truck accidents in 1969 was 1,497 out of a total of $38,813^{(3)}$ accidents. A 1974 study $^{(4)}$ based on traffic accidents in Texas indicated 467 fatalities out of 31,128 accidents. Averaging these statistics results in a heavy truck highway fatality rate of $4.2 \times 10^{-8}$ per $\mathrm{km}$.

U.S. rail transportation in $1975^{(5)}$ consisted of 28.0 billion car miles. There were 2384 rail accident deaths in $1975^{(6)}$ resulting in a fatality rate of $5.4 \times 10^{-8}$ per car-km. 
TABLE G.1 Population Doses for Postulated Spent Fuel Shipping Accidents

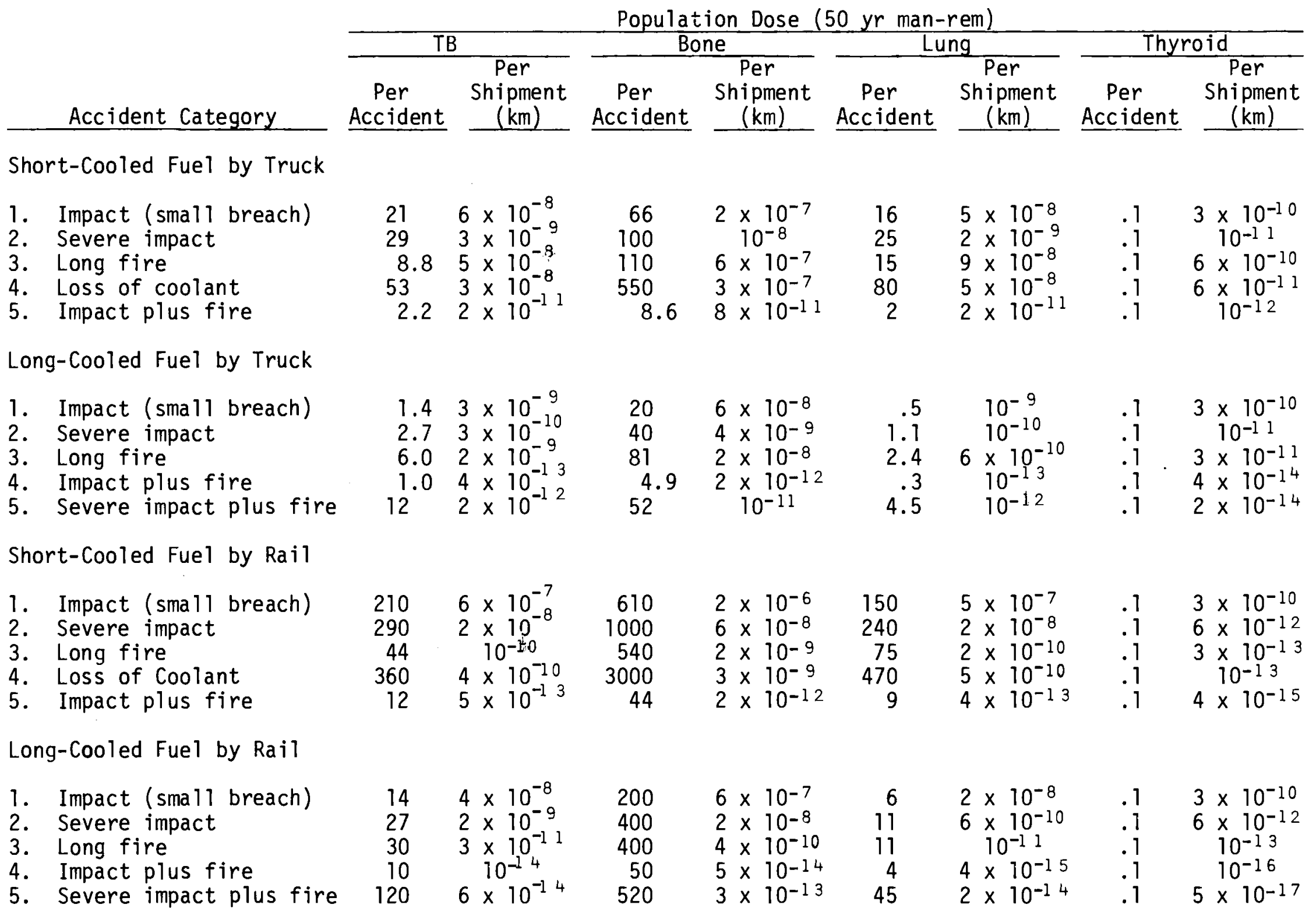




\section{REFERENCES}

1. H. K. Elder, An Assessment of the Risk of Transporting Spent Nuclear Fuel by Truck, PNL-2588, Pacific Northwest Laboratory, Richland, Washington, November 1978.

2. R. K. Clarke, J. T. Foley, W. F. Hartman and D. H. Larson, Severities of Transport Accidents-Vol IV-Motor Carriers, SLA-74-0001, Sandia Laboratories, Albuquerque, New Mexico, July 1976.

3. WASH-1238, Environmental Survey of Transportation of Radioactive Materials To and From Nuclear Power Plants, USAEC - Directorate of Regulatory Standards, December 1972.

4. R. E. Rhoads, An Assessment of the Risk of Transporting Gasoline by Truck, PNL-2133, Pacific Northwest Laboratory, Richland, Washington, November 1978.

5. Yearbook of Railroad Facts, 1976 Edition, published by the Economics and Finance Department of Association of American Railroads, 19201 Street, N.W., Washington, D.C.

6. Transportation Safety Information Report for 1975, published by DOT Transportation Systems Centers Information Division (TSC-220). 


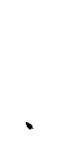




\section{ALARA DISTRIBUTION}

No. of

Copies

Tom Alexander

Department of Energy

Office of Technology Impacts

EV-212, MS-4G065

Forrestal Bldg.

Washington, DC 20585

G. C. Allen, Jr.

Sandia National Laboratories

Division 4552

Albuquerque, NM 87185

John Allen

Material Transportation Bureau

400 Seventh Street, S.W.

Washington, DC 20590

S. Aoki

Research Laboratory for Nuclear Reactors

Tokyo Institute of Technology

Ookayama, Meguroku, Tokyo 152

JAPAN

\section{T. Anderson}

Department of Energy

M/S B-107

Washington, DC 20545

A. L. Babb

Department of Nuclear

Engineering

Benson $\mathrm{Ha} 11$

University of Washington

Seattle, WA 98195

T. Baer

Nuclear Engineering $\mathrm{Co}$.

Louisville, KY 40201

George Bailey

Washington Public Power

Supply System

3000 George Washington Way

Richland, WA 99352
No. of

Copies

R. F. Barker

International Atomic Energy Agency

A-1011 Vienna

Austria

C. B. Bartlett

Nuclear Regulatory Commission

Washington, DC 20555

G. D. Bell

United Kingdom Atomic Energy

Authority

Safety and Reliability

Directorate

Warrington WA3 4NE

UNITED KINGDOM

L. Benner

National Transportation Safety Board

Department of Transportation

Washington, DC 20594

K. M. Bertram

Argonne National Laboratory (EES-17)

9700 S. Cass Avenue

Argonne, IL 60514

W. F. Black

Hazardous Materials Branch

Nassif Building

Federal Railroad Administration

Department of Transportation

Washington, DC 20590

W. A. Brobst

The Transport Environment

SR 285 01d Squaw Drive

Kitty Hawk, NC 27949

J. Buck

Nuclear Fuel Services

Erwin, TN 37650 
No. of

Copies

T. A. Butler

University of California

Los Alamos Scientific Laboratory

P.0. Box 1663

Los Alamos, NM 87545

M. J. Cardu110, Director

Office of Energy Supply

and Transportation

Department of Energy

M/S 3344

Washington, DC 20545

J. M. Cece

DOE/ESED

EV-132, E-201

Washington, DC 20545

R. B. Chitwood

Division of Transportation and

Fuel Storage

$\mathrm{M} / \mathrm{S}, \mathrm{B}-107$

Department of Energy

Washington, DC 20545

A. A. Churm

Chicago Patent Group

DOE Chicago Operations Office

9800 South Cass Avenue

Argonne, IL 50439

Combustion Engineering, Inc.

Windsor, CT 06095

J. S. Corbett

ChemNuclear Systems, Inc.

P.0. Box 1866

Bellevue, WA 98009

J. Counts

DOE/ESED

$M / S, E V-13, E-201$

Department of Energy

Washington, DC 20545

27 DOE Technical Information Center
No. of

Copies

D. A. Edling

Mound Laboratories

P.0. Box 32

Miamisburg, $\mathrm{OH} 45342$

Ken Eger

G.E. Spent Fuel Services Operation

7555 E. Collins Road

Morris, IL 60450

J. Edlow

Edlow International

1100 17th Street N.W.

Washington, DC 20036

F. P. Falci

Department of Energy

M/S B-107

Washington, DC 20545

D. L. Ferguson

Director, Nuclear Energy Programs

Department of Energy

Washington, DC 20545

N. C. Finley

Fuel Cycle Risk Analysis

Division 4413

Sandia National Laboratories

Albuquerque, NM 87185

J. T. Foley

Sandia National Laboratories

Division 5522

Albuquerque, NM 87185

C. P. Furber

Research and Test Department

Association of American

Railroads

1920 "L" Street N.W.

Washington, DC 20036 
No. of

Copies

R. F. Garrison

DOE/ESED

EV-132, E-201

Washington, DC 20545

Dr. R. Girardi

Euratom

21020 Centro Furatomdi

Ispra (Varesse)

ITALY

T. S. Glickman

Transportation Systems Center

Kendall Squire

Cambridge, MA 02142

E. P. Goldfinch

Safeguards Branch

Nuclear Health and Safety Department

Courtenay House

18 Warwick Lane

London F C4P 4EB

UNITED KINGDOM

M. Gordon

Atomic Industrial Forum

7101 Wisconsin Avenue

Washington, DC 20014

(5) J. Greenborg

GPA Surface Corp.

TMI Nuclear Station

P.0. Box 480

Middletown, PA 17057
A. Grella
Office of Inspection and Enforcement
USNRC
Washington, DC 20555
R. J. Hall
Office of Nuclear Waste Isolation
Project Management Division
Battelle
505 King Avenue
Columbus, $\mathrm{OH} 43201$

No. of

Copies

E. C. Hardin, Jr.

DOE Albuquerque

Operations Office

P.0. Box 5400

Albuquerque, NM 87115

Alexandria Holufowich

Nucleonics Week

1221 Avenue of the Americas

New York, NY 10020

Richard Horn

Office of Systems Research and Analysis

Transportation Systems Center

Department of Transportation

Cambridge, MA 02142

H. Hubner

Bundesanstalt für Materialprufung

Unter den Eichen 87

D-1000 Berlin 45 (West)

GERMANY, FED. REPUBLIC

K. Ikeda

Science and Technology Agency

2-2-1 Kasumigaseki,

Chiyoda-ku, Tokyo

JAPAN

Dr. J. Jacquemin

Office of Minister für Arbeit, Gesundheit, und Socialies des Landes NRW

Landeshaus

4000 Dusseldorf

GERMANY, FED. REPUBLIC

(4) R. M. Jefferson

Sandia National Laboratories

Dept. 4550

Attn: TTC Library (3)

TTC Master File (1)

Albuquerque, NM 87185

G. P. Jones

University of Southern

California

University Park

Los Angeles, CA 90007 
No. of

Copies

R. H. Jones

P.0. Box 24033

San Jose, CA 95125

G. Kinchin

UKAEA

Risley, Lancaster

ENGLAND

Pat Kranach

Westinghouse Electric

Advanced Energy Systems Division

P.0. Box 10864

Pittsburg, PA 15236

W. E. Kreger

Chief Radiological Assessment Branch

Nuclear Regulatory Commission

Washington, DC 20555

I. N. Lafontaine

Belgonucleaire

Rue de Champ de Mars 25

B-1050 Bruxelles

BELGIUM

G. Lapier

Babcock \& Wilcox Co.

Apollo, PA 15613

M. J. Lawrence

Dept. of Energy

M/S B-107

Washington, DC 20545

M. Litterman

Portland General Electric

121 S.W. Salmon St.

Portland, OR 97204

G. C. Loud

Tri-State Motor Transit Co.

P.0. Box 113

Joplin, MD 64801
No. of

Copies

R. Y. Lowrey

Department of Energy

M/S B-107

Washington, DC 20545

R. E. Luna

Sandia National Laboratories

Division 4551

Albuquerque, NM 87185

D. G. Maxwe 11

N. L. Industries

Nuclear Division

Foot of West Street

Wilmington, DE 19801

Bob Maxwel1

Office of Technology Assessments

U.S. Congress

Washington, DC 20510

C. H. Mayer

Tri-State Motor Transit Co., Inc.

P.0. Box 113

Joplin, MO 64801

S. A. Maman

Fuel Recycle Waste Management

Program

Whiteshell Nuclear Research

Establishment

Pinewa, Manitoba ROE ILO

CANADA

J. D. McClure

Sandia National Laboratories

Division 4551

Albuquerque, NM 87185

N. J. McCormack

Department of Nuclear

Engineering

Benson $\mathrm{Hall}$

University of WA

Seattle, WA 98195 
No. of

Copies

C. McDonald

Nuclear Regulatory Commission

Washington, DC 20555

H. F. McDonald

CEGB

Berkeley Nuclear Labs

Berkeley

Gloucestershire GL139PB

UNITED KINGDOM

Susan Metzler

System Communications

N.E. Utilities

P.0. Box 270

Hartford, CT 06101

S. Meyers

Department of Energy

M/S B-107

Washington, DC 20545

R. M. Moser

DOE Chicago Operations Office 9800 South Cass Avenue

Argonne, IL 60439

Major General John Murray

Association of American

Railroads

1929 "L" Street, N.W.

Washington, DC 20036

D. Okrent

Department of Engineering and Applied Science

University of California

Los Angeles, CA 90024

A. Ondedera

Hitachi Shipbuilding and Engineering Co., Ltd.

5-4 Kakurajima, Kitano-cho

Konohana-ku, Osaka-shi

JAPAN
No. of

Copies

W. G. O'Quinn

DOE Savannah River Operations Office

P.0. Box A

Aiken, SC 29801

Bill Pardue

Office of Nuclear Waste Isolation

505 King Avenue

Col umbus, $\mathrm{OH} 43201$

R. W. Peterson

Battelle Memorial Institute

Office of Nuclear Waste Isolation

505 King Avenue

Columbus, $\mathrm{OH} 43201$

Marlene Phillips

Maritime Research Board

National Academy of Sciences

2101 Constitution Avenue N.W.

Washington, DC 20418

R. B. Pope

Sandia National Laboratories

Division 4552

Albuquerque, NM 87185

B. Posik

Chem-Nuclear Systems, Inc.

Barnwe11, SC 29812

Prof. Norman C. Rasmussen

Massachusetts Institute of Technology

Cambridge, MA 02139

R. R. Rawl

Materials Transportation Bureau

Department of Transportation

Washington, DC 20545

R. L. Reese

Sandia National Laboratories

Division 4551

Albuquerque, NM 87185 
No. of

Copies

J. L. Ridihalgh

Ridihalgh, Eggers \& Associates

2112 Iuka Avenue

Columbus, $\mathrm{OH} 43201$

J. L. Russell

Office of Radiation Programs

AW-459, EPA

401 M Street S.W.

Washington, DC 20460

L. D. Santman

Materials Transportation Bureau Department of Transportation 2100 Second Street S.W. Washington, DC 20590

A. L. Schmeig

National Transportation Safety Board

Department of Transportation

Washington, DC 20594

Dr. Schmidt-Kuester

Beim Bundesminister für

Forschung and Technologie

Stresemanns trasse 2

5300 Bonn

GERMANY

B. Schulz-Forbert

Bundesanstalt für Materialprufung

Unter den Eichen 87

D-1000 erl in 45 (West)

GERMANY, FED. REPUBLIC

L. Shappert

Union Carbide Corporation

Oak Ridge National Laboratories

P.0. Box X

Oak Ridge, TN 37830

J. A. Sisler

Mail Stop/B107

Transportation and Fuel Storage

Department of Energy

Washington, DC 20545
No. of

Copies

Y. Sousselier

CEA/CEN

B.P. No. 6

F-92260 Fontenay-aux-Roses

FRANCE

M. Stammler

Battelle Institute, e.v.

Am Romerhof 35

600 Frankfurt Main 90

GERMANY

C. Starr

Electrical Power Research Institute

P.0. Box 10412

Palo Alto, CA 94304

G. L. Stukenbroeker

N.L. Industries, Inc.

Nuclear Transportation Dept.

P.0. Box 2046

Wilmington, DE 19899

G. R. Swindell

International Atomic Energy Agency

A-1011 Vienna, AUSTRIA

W. R. Taylor

Atomic Energy of Canada Ltd.

Chalk River Laboratories

Chalk River, Ontario KOJIJO

CANADA

W. R. Teer

Transnuclear Inc.

One N. Broadway

White Plains, NY 10601

D. H. Teeter

Puget Sound

Council of Governments

216 First Avenue South

Seattle, WA 98104 
No. of

Copies

M. Tomlinson

White Shell Nuclear Research Establishment

Pinewa, Manitoba ROE ILO CANADA

K. A. Trickett

Division of Reactor Development and Demonstration

Department of Energy

Germantown, MD 20014

P. T. Tuite

Hittman Nuclear and Development Corporation

9190 Red Branch Rd.

Columbia, MD 21045

L. L. Turner

DOE Savannah River Operations Office

P.0. Box A

Aiken, SC 29801

W. E. Vesely

Nuclear Regulatory Commission

Washington, DC 20555

J. Walker

California Energy Resources Conservation and Development Commission

1111 Howe Avenue

Saramento, CA 95825

R. Williams

Electrical Power Research Institute

P.0. Box 10412

Palo Alto, CA 94304

E. J. Wilson

Department of Transport

Dangerous Goods Branch

2 Marsham St.

London SW 1

ENGLAND
No. of

Copies

Ichiro Yabe

Nuclear Safety Research Association

Room 1037, National Press

Building

14 th and F St. N.W.

Washington, DC 20004

H. R. Yoshimura

Sandia National Laboratories

Division 4552

Albuquerque, NM 87185

ONSITE

DOE-Richland Operations Office

J. C. Cummings

J. M. Peterson

H. E. Ransom

J. J. Schreiber

M. W. Shupe

Pacific Northwest Laboratory

W. B. Andrews

W. J. Bair

M. J. Budden

L. W. Brackenbush (5)

N. M. Burleigh (25)

R. A. Burnett

T. D. Chikalla

J. G. Desteese

M. D. Erickson

L. G. Faust

R. M. Fleischman

A. L. Franklin

J. R. Friley

C. A. Geffen-Fowler

H. Harty

M. R. Kreiter

J. R. Lewis

R. C. Liikala

J. W. Litchfield

D. W. Murphy (5)

E. S. Murphy

J. M. Oylear 
No. of

Copies

Pacific Northwest Laboratory (contd)

R. E. Rhoads

J. L. Swanson

L. D. Williams

Technical Information (5)

Publishing Coordination MM (2)

Battelle-Human Affairs Research

Center

C. Cluett

J. A. Hebert

F. A. Morris

C. R. Schuller 